PNL-6575

$U \overline{C-110 / 114}$

$18 \mathrm{~J}$

\title{
Advanced Materials for Solid Oxide Fuel Cells: Hafnium- Praseodymium-Indium Oxide System
}

J. L. Bates

C.W. Griffin

W. J. Weber

June 1988

Prepared for the U.S. Department of Energy under Contract DE-AC06-76RLO 1830

Pacific Northwest Laboratory

Operated for the U.S. Department of Energy

by Battelle Memorial Institute 


\title{
DISCLAIMER
}

This report was prepared as an account of work sponsored by an agency of the United States Government. Neither the United States Government nor any agency thereof, nor Battelle Memorial Institute, nor any or their employees, makes any warranty, expressed or implied, or assumes any legal liability or responsibility for the accuracy, completeness, or usefulness of any information, apparatus, product, or process disclosed, or represents that its use would not infringe privately owned rights. Reference herein to any specific commercial product, process, or service by trade name, trademark, manufacturer, or otherwise does not necessarily constitute or imply its endorsement, recommendation, or favoring by the United States Government or any agency thereof, or Battelle Memorial Institute. The views and opinions of authors expressed herein do not necessarily state or reflect those of the United States Government or any agency thereof, or Battelle Memorial Institute.

\author{
PACIFIC NORTHWEST LABORATORY \\ operated by \\ BATTELLE MEMORIAL INSTITUTE \\ for the \\ UNITED STATES DEPARTMENT OF ENERGY \\ under Contract DE-AC06-76RLO 1830
}

\begin{tabular}{|c|c|}
\hline \\
\hline \multicolumn{2}{|c|}{$\begin{array}{c}\text { Printed in the United States of America } \\
\text { Available from } \\
\text { National Technical Information Service } \\
\text { United States Department of Commerce } \\
5285 \text { Port Royal Road } \\
\text { Springfield, Virginia } 22161\end{array}$} \\
\hline \multicolumn{2}{|c|}{$\begin{array}{l}\text { NTIS Price Codes } \\
\text { Microfiche A01 }\end{array}$} \\
\hline \multicolumn{2}{|c|}{ Printed Copy } \\
\hline Pages & $\begin{array}{l}\text { Price } \\
\text { Codes }\end{array}$ \\
\hline $001-025$ & $\mathrm{~A} 02$ \\
\hline $026-050$ & A03 \\
\hline $051-075$ & $\mathrm{~A} 04$ \\
\hline $076-100$ & $\mathrm{~A} 05$ \\
\hline $101-125$ & $A 06$ \\
\hline $126-150$ & A07 \\
\hline $157-175$ & $A 08$ \\
\hline $176-200$ & A09 \\
\hline $201-225$ & A010 \\
\hline $226-250$ & A011 \\
\hline $251-275$ & A012 \\
\hline $276-300$ & A013 \\
\hline
\end{tabular}


ADVANCED MATERIALS FOR SOLID OXIDE FUEL CELLS: HAFNIUM-PRASEODYMIUMINDIUM OXIDE SYSTEM
J. L. Bates
C. W. Griffin
W. J. Weber

June 1988

Prepared for the U.S. Department of Energy under Contract DE-AC06-76RLO 1830

Pacific Northwest Laboratory Richland, Washington 99352 


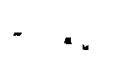

- 


\section{SUMMARY}

The $\mathrm{HfO}_{2}-\mathrm{PrO}_{1.83^{-I n} \mathrm{O}_{3}}$ system has been studied at the Pacific Northwest Laboratory to develop alternative, highly electrically conducting oxides as electrode and interconnection materials for solid oxide fuel cells. A coprecipitation process was developed for synthesizing single-phase, mixed oxide powders necessary to fabricate powders and dense oxides. A ternary phase diagram was developed, and the phases and structures were related to electrical transport properties. Two new phases, an orthorhombic $\mathrm{PrInO}_{3}$ and a rhombohedral $\mathrm{Hf}_{2} \mathrm{In}_{2} \mathrm{O}_{7}$ phase, were identified. The highest electronic conductivity is related to the presence of a bcc, $\mathrm{In}_{2} \mathrm{O}_{3}$ solid solution (ss) containing $\mathrm{HfO}_{2}$ and $\mathrm{PrO}_{1.83}$. Compositions containing more than $35 \mathrm{~mol} \%$ of the $\mathrm{In}_{2} \mathrm{O}_{3}$ ss have electrical conductivities greater than $10^{-1} \cdot(\mathrm{ohm}-\mathrm{cm})^{-1}$, and the two or three phase structures that contain this phase appear to exhibit mixed electronic-ionic conduction. The high electrical conductivities and structures similar to the $\mathrm{Y}_{2} \mathrm{O}_{3}$-stabilized $\mathrm{ZrO}_{2}\left(\mathrm{HfO}_{2}\right)$ electrolyte give these oxides potential for use as cathodes in solid oxide fuel cells. 
.

. 
CONTENTS

SUMMARY

1.0 INTRODUCTION . . . . . . . . . . . . . . . . . 1.1

2.0 SAMPLE PREPARATION . . . . . . . . . . . . . . . . . 2.1

2.1 POWDER SYNTHESIS . . . . . . . . . . . . . . 2.1

2.2 POWDER PROCESSING . . . . . . . . . . . . . . 2.1

2.3 COMPACTION . . . . . . . . . . . . . . . 2.2

2.4 SINTERING . . . . . . . . . . . . . . . . 2.2

3.0 PHASE EQUILIBRIA . . . . . . . . . . . . . . . 3.1

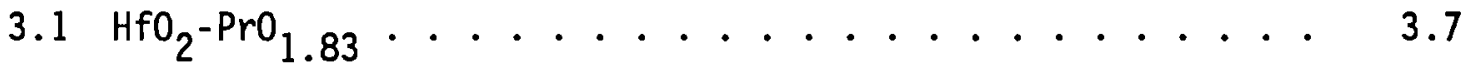

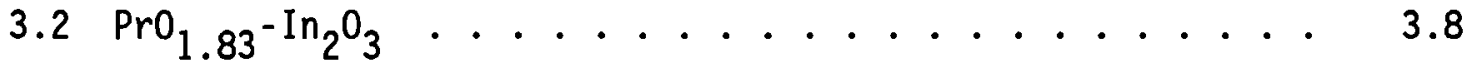

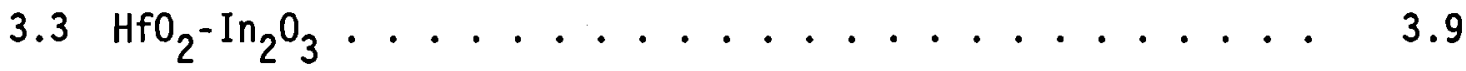

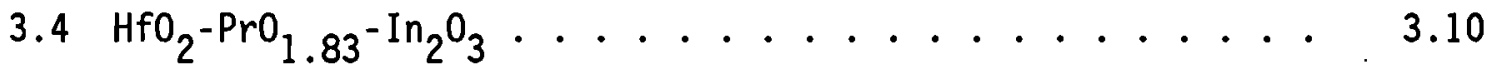

4.0 ELECTRICAL TRANSPORT PROPERTIES . . . . . . . . . . . . 4.1

4.1 ELECTRICAL CONDUCTIVITY . . . . . . . . . . . . 4.1

4.1.1 $\mathrm{HfO}_{2}-\mathrm{In}_{2} \mathrm{O}_{3}$. . . . . . . . . . . . . . . 4.2

4.1.2 $\mathrm{HfO}_{2}-\mathrm{PrO}_{1.83}-\mathrm{In}_{2} \mathrm{O}_{3}$. . . . . . . . . . . . . 4.6

4.1.3 $\mathrm{HfO}_{2}-\mathrm{PrO}_{1.83}-\mathrm{In}_{2} \mathrm{O}_{3}$ Containing $\mathrm{Yb}_{2} \mathrm{O}_{3} \ldots \ldots . . . .4 .12$

4.1.4 Heat Treatment .............. 4.12

4.1.5 0xygen Pressure ............... 4.17

4.2 SEEBECK COEFFICIENTS . . . . . . . . . . . . . 4.21

4.3 TRANSFERENCE NUMBERS . . . . . . . . . . . . . . 4.22

5.0 CONCLUSIONS . . . . . . . . . . . . . . . . . 5.1

6.0 ACKNOWLEDGMENTS . . . . . . . . . . . . . . . . . 6.1

7.0 REFERENCES .......................... . . . 7.1 


\section{FIGURES}

$3.1 \mathrm{HfO}_{2}-\mathrm{PrO}_{1.83} \mathrm{In}_{2} \mathrm{O}_{3}$ Phase Diagram at $1812 \mathrm{~K}$ in Air . . . . 3.7

4.1 Electrical Conductivity for $\mathrm{HfO}_{2}-\mathrm{In}_{2} \mathrm{O}_{3}, \mathrm{ZrO}_{2}\left(\mathrm{Y}_{2} \mathrm{O}_{3}\right)$ Single Crystal, and $\mathrm{HfO}_{2}\left(\mathrm{Y}_{2} \mathrm{O}_{3}\right)^{2}$. ...?....... 4.2

4.2 Activation Energy and Electrical Conductivity at $1000 \mathrm{~K}$ of $\mathrm{HfO}_{2}-\mathrm{In}_{2} \mathrm{O}_{3}$ as a Function of $\mathrm{mol} \% \mathrm{In}_{2} \mathrm{O}_{3} \ldots . . . . .4 .5$

4.3 Electrical Conductivity of $\mathrm{HfO}_{2}-\mathrm{PrO}_{1.83}-\mathrm{In}_{2} \mathrm{O}_{3}$ Including Some with a Small Percentage of $\mathrm{Yb}_{2} \mathrm{O}_{3}$............ 4.8

4.4 Electrical Conductivity of $\mathrm{HfO}_{2}-\mathrm{PrO}_{1} 83-\mathrm{In}_{2} \mathrm{O}_{3}$ at 923,1273 , and $1667 \mathrm{~K}$ as a Function of $\mathrm{In}_{2} \mathrm{O}_{3}$ Content 83. . . . . . . . 4.5 Electrical Conductivity at $1273 \mathrm{~K}$ of $\mathrm{HfO}_{2}-\mathrm{PrO}_{1}{ }^{-}-\mathrm{In}_{2} \mathrm{O}_{3}$
Containing Small Amounts of $\mathrm{Yb}_{2} \mathrm{O}_{3}$ as a Fanction $\mathrm{O}_{\mathrm{f}}$
(a) $\operatorname{In}_{2} \mathrm{O}_{3}$ Content and
(b) $\mathrm{In}_{2} \mathrm{O}_{3}^{2}$ Solid Solution

4.6 Electrical Conductivity of $(0.94-\mathrm{x}) \cdot\left[0.5 \mathrm{HfO}_{2} 0.5 \mathrm{PrO}_{1.83}\right] \cdot$

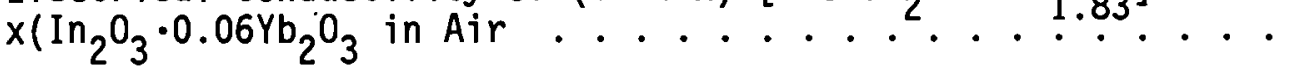

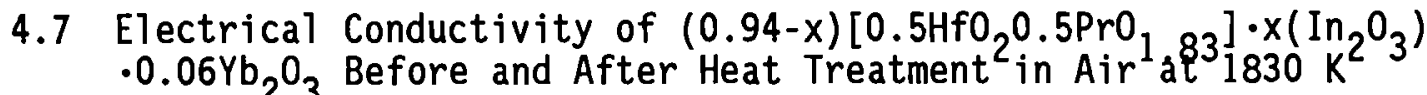
for 48 hours $(H T) \ldots \ldots \ldots$

4.8 Electrical Conductivity at 1000 and $1273 \mathrm{~K}$ as a Function of ${ }_{\text {with }} \mathrm{O}_{3}$ and $\mathrm{In}_{2} \mathrm{O}_{3}$ Solid Solution Content for $\mathrm{HfO}_{2}-\mathrm{PrO}_{1.83} \mathrm{Ph}_{2} \mathrm{In}_{2} \mathrm{O}_{3}$

4.9 Electrical Conductivity of $0.39 \mathrm{HfO}_{2} \cdot 0.3 \mathrm{PrO}_{1.83^{\circ}}$ $0.208 \operatorname{In}_{2} \mathrm{O}_{3} \cdot 0.01 \mathrm{Yb}_{2} \mathrm{O}_{3}$ in Oxygen and in Air $1.83^{\circ}$

4.10 Electrical Conductivity of $0.39 \mathrm{HfO}_{2} \cdot 0.39 \mathrm{PrO}_{1.83} \cdot 0.21 \mathrm{Yb}_{2} \mathrm{O}_{3}$ as a Function of Oxygen Pressure . . . . . . . . ? . .

4.11 Electrical Conductivity of $0.31 \mathrm{HfO}_{2} \cdot 0.39 \mathrm{PrO}_{1.83} \cdot 0.2 \mathrm{In}_{2} \mathrm{O}_{3} \cdot$ $0.02 \mathrm{Yb}_{2} \mathrm{O}_{3}$ as a Function of Oxygen Pressure $1.83 .{ }^{2} .{ }^{\circ}$...

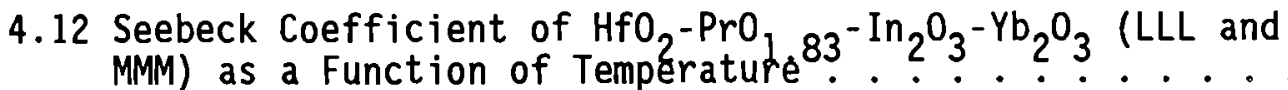




\section{$\underline{\text { TABLES }}$}

3.1 Phases and Lattice Parameters of $\mathrm{HfO}_{2}-\mathrm{In}_{2} \mathrm{O}_{3} \ldots \ldots . \ldots 3.2$

3.2 Phases and Lattice Parameters of $\mathrm{HfO}_{2}-\mathrm{PrO}_{1.83}-\mathrm{In}_{2} \mathrm{O}_{3} \ldots \ldots . . .3$

3.3 Phases and Lattice Parameters of $\mathrm{HfO}_{2}-\mathrm{PrO}_{1.83}-\mathrm{In}_{2} \mathrm{O}_{3}-\mathrm{Yb}_{2} \mathrm{O}_{3} \ldots 3.6$

4.1 Composition and Electrical Conductivity of $\mathrm{HfO}_{2}-\mathrm{In}_{2} \mathrm{O}_{3} \ldots \ldots$

4.2 Composition and Electrical Conductivity of $\mathrm{HfO}_{2}-\mathrm{PrO}_{1.83}-\mathrm{In}_{2} \mathrm{O}_{3}-\mathrm{Yb}_{2} \mathrm{O}_{3} \ldots \ldots . . . . . . . .4 .7$

4.3 Composition of $(1-\mathrm{x})\left(0.277 \mathrm{HfO}_{2} \cdot 0.63 \mathrm{PrO}_{1.83} \cdot 0.10 \mathrm{Yb}_{2} \mathrm{O}_{3}\right) \cdot \mathrm{xn}_{2} \mathrm{O}_{3} \cdot 4.8$

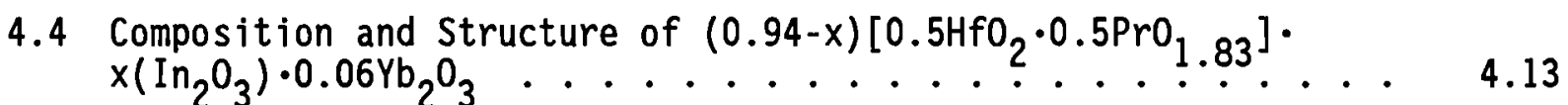

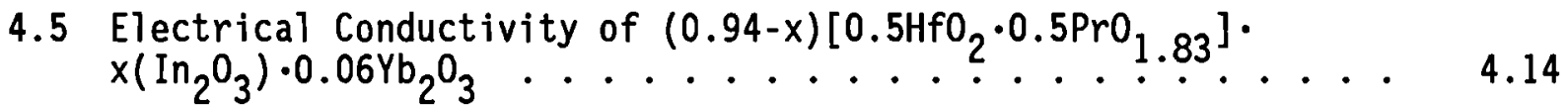

4.6 Transference Numbers for $\mathrm{FC}-133-1 \ldots . . . \ldots 4.23$ 


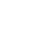

$\cdot$

-

- 


\subsection{INTRODUCTION}

Use of fuel cells is a clean and efficient means for the direct chemical conversion of fossil fuels to electrical energy. A fuel cell consists of an electrolyte sandwiched between two electrodes which converts the chemical energy of a fuel to electrical energy without combustion. The fuel, such as hydrogen, and the oxidant, such as air, are exposed to the cell's anode and cathode, respectively. The fuel is oxidized catalytically at the fuel electrode with oxygen that has been transported through the ionically conducting electrolyte. Electrons liberated at the anode are conducted through an external circuit to the air electrode where more oxygen ions are produced.

The solid oxide fuel cell (SOFC) is receiving increased consideration as a high-temperature fuel cell (see Dollard and Brown 1986; Feduska and Isenberg 1983; Fee et a1. 1983, 1986; I senberg 1985; Penner 1985). The SOFC operates near $1273 \mathrm{~K}$ and the high temperatures allow the direct reforming of natural gas or methane to hydrogen. The state-of-the-art SOFC uses a thin, dense, solid electrolyte of $\mathrm{Y}_{2} \mathrm{O}_{3}$-stabilized $\mathrm{ZrO}_{2}$ with porous electrodes (Isenberg 1985 and Fee et al. 1986). The air electrode or cathode is strontium-doped lanthanum manganite with a nickel- $\mathrm{Y}_{2} \mathrm{O}_{3}$-stabilized $\mathrm{ZrO}_{2}$ composite as the fuel electrode or anode. The current interconnection is Sror Mg-doped lanthanum chromite. These four materials exhibit considerably different thermal properties, unless modified, and generally require different multiple-step fabrication processes. The material properties critical to this multi-component system are 1) thermal compatibility among electrodes, electrolyte, and interconnection; 2) electrochemical and chemical interactions during fabrication and/or operation; 3) bonding at interfaces between materials for good electrical and thermal contacts; 4) high ionic conduction of the electrolyte; 5) high electronic (with some oxygen-ion) conduction of the porous electrodes; and 6) high electronic conduction of the interconnection in both oxidizing and reducing conditions.

A basic issue is the fabrication processes for these different material components. Present state-of-the-art methods are complex and/or require a different process for each material component (Isenberg 1985). The multiple-step operations result in limitations on processing temperatures, 
processing methods, and material compositions and structures. For example, the application and fabrication of each component must be performed sequentially at a lower temperature than the preceding process. In addition, materials with better properties may be available, but cannot be used because of process limitations (Fee et al. 1986). Thus, electrode and interconnection materials with suitable properties are required that can be fabricated using fewer and more simple methods but with the required thermal, electrochemical, mechanical, and electrical properties. Ideally, the electrodes and electrolyte and possibly the interconnection could be fabricated into the final cell geometry simultaneously using the same fabrication method.

The purpose of this study, which was conducted at Pacific Northwest Laboratory (PNL), was to investigate materials based on rare-earth-stabilized $\mathrm{HfO}_{2}$ as advanced SOFC electrode and interconnection materials. The approach was to investigate highly electrically conducting oxides with structural, thermal, and fabrication characteristics similar to the $\mathrm{Y}_{2} \mathrm{O}_{3}$-stabilized $\mathrm{ZrO}_{2}$ electrolyte, which can be fabricated simultaneously with, and using the same process as, the electrolyte. The new materials may provide 1) improved thermal expansion match with the electrolyte; 2) reduced or non-degrading interactions during fabrication or fuel cell operation among the electrodes, electrolyte, and interconnection; 3) mixed ionic and electronic conduction of the electrodes to enhance the electrode/electrolyte reactions and electrical charge transfer characteristics; and 4) simultaneous fabrication of electrode/electrolyte components. $\mathrm{HfO}_{2}$ was used in this study because of its high thermal stability, isomorphic with electrical, phase, and structural properties to $\mathrm{ZrO}_{2}$. These rare-earth-containing hafnates were studied initially as potential electrode materials for magnetohydrodynamics direct energy conversion (Bates and Marchant 1978, 1986; Marchant and Bates 1980a,b). These studies were subsequently expanded and directed toward application for use as electronically conducting oxides for solid oxide fuel cells (Bates and Griffin 1986). The current study has recently been extended to the $\mathrm{ZrO}_{2}-\mathrm{PrO}_{1.83}-\mathrm{In}_{2} \mathrm{O}_{3}$ system, which will be the subject of a future report. 
This report describes the research and development of advanced SOFC electrode and interconnection materials based on the $\mathrm{HfO}_{2}-\operatorname{PrO}_{1.83}\left(\mathrm{RE}_{x} \mathrm{O}_{y}\right)$ $\mathrm{In}_{2} \mathrm{O}_{3}$ system. The synthesis and fabrication processes, electrical transport, and phase equilibria of this system are described. 
. 


\subsection{SAMPLE PREPARATION}

The samples were formed from oxides that were coprecipitated to form powders which were dried and calcined. These powders were pressed to form green bars which were sintered at 1850 to $1875 \mathrm{~K}$.

\subsection{POWDER SYNTHESIS}

The mixed oxides were synthesized using a coprecipitation process similar to that reported by Dole (1978). This was critical to the preparation of powders used in fabricating high-density and homogeneous samples with reproducible physical and structural properties. The basic coprecipitation process consists of dissolving the nitrates of praseodymium and indium with the hydrated oxychloride of hafnium in water. The oxychloride forms acids on dissolution. Some of the oxides were formed using solutions of hafnium sulfate instead of the hafnium oxychloride. This produced powders that required little or no ball milling and the elimination of gelatinous precipitates attributed to the presence of chlorides. The gelatinous particles were considered a source of the hard agglomerates that produced inhomogeneous structures.

The solutions were filtered through a $0.2-\mu \mathrm{m}$ millipore filter before mixing to remove undissolved solids and impurities, such as silicates, which result in nucleation sites for particles during coprecipitation and encourage the formation of hard agglomerates. The water used in the dissolution was treated by being passed through a reverse osmosis cycle and then distilled.

The mixed acid solutions were added to an ammonium hydroxide solution using a pressure spray through a small orifice which produced acid droplets to less than $100 \mu \mathrm{m}$. The ammonium hydroxide solution was stirred during the introduction of the acid solution. The final $\mathrm{pH}$ of the liquid was 8.5. The precipitates were separated from the liquid by vacuum filtering and sequentially washed with water, acetone, toluene, and then acetone. All organic solvents and wash were of the highest reagent grade. This washing was necessary to remove oily residues that can react with the bal1 $\mathrm{mill}$ materials, thereby inhibiting sintering. 


\subsection{POWDER PROCESSING}

The powders were dried and calcined at 1073 to $1273 \mathrm{~K}$ in air for 4 hours. The calcined powders were ball-milled for up to 960 minutes in a neoprene-lined mill using $\mathrm{Y}_{2} \mathrm{O}_{3}$-stabilized $\mathrm{ZrO}_{2}$ balls in a Freon® TF milling fluid. The final surface areas of the powders, as determined by BET, varied between 12 and $17 \mathrm{~m}^{2} / \mathrm{g}$. The ball milling improved sintering densities to greater than $95 \%$ theoretical density.

\subsection{COMPACTION}

The powders were slugged at $69 \mathrm{MPa}(10,000 \mathrm{psi})$ before passing through a -145 Tyler mesh screen. The slugged and granular powder was pressed uniaxially in steel dies at $152 \mathrm{MPa}(22,000 \mathrm{psi})$ into a right cylinder and discs. Humidity in water-saturated air provided an adequate binder. For final compaction, the green bars were isostatically pressed in doubleencapsulated plastic evacuated containers in a water-soluble oil at $228 \mathrm{MPa}$ $(33,000 \mathrm{psi})$.

\subsection{SINTERING}

The bars and discs were set on yttria-stabilized $\mathrm{ZrO}_{2}$ furnace hardware and surrounded with a high-temperature calcined powder of a composition near that of the sample. The oxides were sintered between 1850 and $1875 \mathrm{~K}$ in air for 8 to 20 hours at temperature with 5-hour heatup and cooldown cycles. Sintering times and temperatures were selected according to the desired final density, powder characteristics, and oxide composition. Generally, the samples containing indium oxide were sintered at the lower temperature.

Each bar was sectioned and samples were cut from the center of the bar or disc. Each sample was characterized using x-ray diffraction (XRD) and immersion density. In addition, the compositions of selected samples were analyzed using quantitative energy dispersive $x$-ray spectroscopy (EDX) coupled with scanning electron microscopy (SEM).

(®) Freon is a registered trademark of E.I. DuPont de Nemours Corp., Wilmington, Delaware. 


\subsection{PHASE EQUILIBRIA}

The ternary phase diagram for $\mathrm{HfO}_{2}-\mathrm{PrO}_{1.83}-\mathrm{In}_{2} \mathrm{O}_{3}$ was determined at $1823 \mathrm{~K}$ in air using optical microscopy, SEM coupled with EDX, XRD, and 1 imited transmission electron microscopy (TEM) with electron diffraction. The binary-phase relationships were determined for the $\mathrm{HfO}_{2}-\mathrm{In}_{2} \mathrm{O}_{3}$ and $\mathrm{PrO}_{1.83}-\mathrm{In}_{2} \mathrm{O}_{3}$ systems. The $\mathrm{HfO}_{2}-\mathrm{PrO}_{1.83}$ phase relationships had been reported previously (Kravchinskaya et al. 1973) and only selected compositions were used to confirm the binary diagram. The structures and compositions of samples inside the ternary were coupled with these binary-phase diagram data to generate a ternary diagram.

The ternary-phase diagram was developed using the general phase rules associated with ternary-phase diagrams, the compositions of phases determined using quantitative EDX and $x$-ray diffraction crystallographic data, and the reported $\mathrm{HfO}_{2}-\mathrm{Pr}_{6} \mathrm{O}_{11}$ binary diagram. These data are summarized in Table 3.1, 3.2, and 3.3. Quantitative SEM-EDX is a relatively new technique employed to study phase equilibria. In multiple-phase fields, the overall composition is determined quantitatively from large areas containing all phases. The composition of each separate phase is determined by focusing the electron beam on single-phase crystallites of sufficient size so that the beam does not penetrate or scatter beyond the volume of the single-phase region. The smallest volume examined must exceed the $1-\mu \mathrm{m}$-diameter and 1- $\mu \mathrm{m}$-deep volume probed by the penetration and scatter of the $10-\mathrm{kV}$ electron beam. Lower beam voltages result in instabilities; higher voltages increase the volume affected by the beam and reduced the resolution. These determined compositions represent the vortex compositions of a three-phase region and points on opposite boundary lines of a two-phase system.

The EDX is calibrated using single-crystal $\mathrm{HfO}_{2}$, sintered $\mathrm{In}_{2} \mathrm{O}_{3}$, and sintered, single-phase, binary compositions of $\mathrm{In}_{2} \mathrm{O}_{3}-\mathrm{PrO}_{1.83}$ and $\mathrm{HfO}_{2}-\mathrm{In}_{2} \mathrm{O}_{3}$. These binary compositions were verified by wet chemistry. The accuracy of the quantitative SEM-EDX was determined to be within $\pm 1 \mathrm{~mol} \%$. This is achieved by reducing the electron beam voltage to $10 \mathrm{~kW}$ and maintaining that voltage for each spot determination. The data are recorded and the spectra 
TABLE 3.1. Phases and Lattice Parameters of $\mathrm{HfO}_{2}-\mathrm{In}_{2} \mathrm{O}_{3}$ and $\mathrm{PrO}_{1.83^{-I n}} \mathrm{O}_{3}$

\begin{tabular}{|c|c|c|c|c|c|c|c|c|c|c|}
\hline \multirow{2}{*}{\multicolumn{3}{|c|}{ Composition, mol\% }} & \multicolumn{8}{|c|}{ Phases and Lattice Parameters, $\mathrm{nm} \times 10^{-1}$} \\
\hline & & & \multirow[b]{2}{*}{ Monocl inic } & \multirow{2}{*}{$\begin{array}{l}f c c \\
\text { Fluorite }\end{array}$} & \multirow{2}{*}{$\begin{array}{c}\text { Rhom- } \\
\text { bohedral }\end{array}$} & \multirow{2}{*}{$\begin{array}{c}f c c \\
\text { Pyrochlore }\end{array}$} & \multirow[b]{2}{*}{$b c c$} & \multicolumn{2}{|c|}{ Orthorhombic } & \multirow[b]{2}{*}{ fcc } \\
\hline $\mathrm{HfO}_{2}$ & $\operatorname{PrO}_{1.83}$ & $\mathrm{In}_{2} \mathrm{O}_{3}$ & & & & & & $a$ & b $\quad c$ & \\
\hline 98 & & 2 & & 5.095 & & & & & & \\
\hline 94 & & 6 & (a) & 5.102 & & & & & & \\
\hline 93 & & 7 & (a) & 5.110 & & & & & & \\
\hline 93 & & 7 & (a) & 5.096 & & & & & & \\
\hline 91 & & 9 & (a) & 5.090 & & & & & & \\
\hline 85 & & 15 & & 5.09 & 5.15 & & & & & \\
\hline 84 & & 16 & & 5.095 & (b) & & & & & \\
\hline 83 & & 17 & & 5.098 & & & & & & \\
\hline 83 & & 17 & (a) & 5.098 & & & & & & \\
\hline 74 & & 26 & & 5.108 & & & & & & \\
\hline 71 & & 29 & & 5.085 & (b) & & & & & \\
\hline 71 & & 29 & & & & 10.714 & & & & \\
\hline 69 & & 31 & & 5.084 & (b) & & & & & \\
\hline 65.5 & & 34.5 & & 5.08 & (b) & & & & & \\
\hline 63 & & 37 & & 5.08 & 5.11 & & & & & \\
\hline 60 & & 40 & & (b) & (b) & & & & & \\
\hline 50 & & 50 & & (b) & & & (c) & & & \\
\hline 20 & & 80 & & & 5.17 & & 10.12 & & & \\
\hline 20 & & 80 & & & (b) & & 10.255 & & & \\
\hline 3 & & 97 & & & & & 10.188 & & & \\
\hline
\end{tabular}


TABLE 3.1. (contd)

Phases and Lattice Parameters, $\mathrm{nm} \times 10^{-1}$

\begin{tabular}{|c|c|c|c|c|c|c|c|c|c|c|c|}
\hline \multirow{2}{*}{\multicolumn{3}{|c|}{ Composition, mol\% }} & \multirow[b]{3}{*}{ Monocl inic } & \multirow{3}{*}{$\begin{array}{c}f c c \\
\text { Fluorite }\end{array}$} & \multirow{3}{*}{$\begin{array}{c}\text { Rhom- } \\
\text { bohedral }\end{array}$} & \multirow{3}{*}{$\begin{array}{c}\text { fcc } \\
\text { Pyrochlore }\end{array}$} & \multirow[b]{3}{*}{$b c c$} & \multirow{2}{*}{\multicolumn{3}{|c|}{ Orthorhombic }} & \multirow{3}{*}{$\mathrm{fcc}$} \\
\hline & & & & & & & & & & & \\
\hline $\mathrm{HfO}_{2}$ & $\operatorname{PrO}_{1.83}$ & $\mathrm{In}_{2} \mathrm{O}_{3}$ & & & & & & a & b & & \\
\hline & 98 & 2 & & & & & & & & & $5.46^{(b)}$ \\
\hline & 91 & 9 & & & & & & 5.67 & 5.92 & 8.18 & 5.46 \\
\hline & 84 & 14 & & & & & & 5.67 & 5.92 & 8.16 & 5.46 \\
\hline & 76 & 24 & & & & & & 5.67 & 5.92 & 8.17 & 5.45 \\
\hline & 60 & 40 & & & & & 10.13 & 5.67 & 5.90 & 8.16 & \\
\hline & 18 & 82 & & & & & 10.13 & (d) & & & \\
\hline & 2 & 98 & & & & & 10.18 & & & & \\
\hline
\end{tabular}

(a) Monoclinic phase present.

(b) fcc fluorite or rhomohedral phase present. Interference made resolution difficult.

(c) bcc sesquoxide solid solution phase present.

(d) Orthrombic phase present. 
TABLE 3.2. Phases and Lattice Parameters of $\mathrm{HfO}_{2}-\operatorname{Pr} 0_{1.83^{-}} \operatorname{In}_{2} \mathrm{O}_{3} \mathrm{p}$

Phases and Lattice Parameters, $\mathrm{nm} \times 10^{-1}$

\begin{tabular}{|c|c|c|c|c|c|c|c|c|c|c|}
\hline \multicolumn{3}{|c|}{ Composition, mol\% } & \multirow[b]{2}{*}{ Monoclinic } & \multirow{2}{*}{$\begin{array}{c}\text { fcc } \\
\text { Fluorite }\end{array}$} & \multirow{2}{*}{$\begin{array}{l}\text { Rhom- } \\
\text { bohedral }\end{array}$} & \multirow{2}{*}{$\begin{array}{c}f c c \\
\text { Pyrochlore }\end{array}$} & \multirow[b]{2}{*}{$b c c$} & \multicolumn{2}{|c|}{ Orthorhombic } & \multirow[b]{2}{*}{$\mathrm{fcc}$} \\
\hline $\mathrm{HfO}_{2}$ & $\operatorname{Pr} 0_{1.83}$ & $\mathrm{In}_{2} \mathrm{O}_{3}$ & & & & & & $a$ & b c & \\
\hline 80 & 10 & 10 & & (a) & 5.128 & & & & & \\
\hline 70 & 7 & 23 & & (a) & 5.131 & & & & & \\
\hline 70 & 10 & 20 & & (a) & 5.128 & & & & & \\
\hline 68 & 20 & 12 & & & & 10.664 & & & & \\
\hline 65 & 18 & 17 & & & 5.164 & & & & & \\
\hline 60 & 30 & 10 & & & & (b) & 10.125 & & & \\
\hline 59 & 7 & 34 & & & 5.13 & & (c) & & & \\
\hline 56 & 20 & 24 & & 5.11 & (a) & 10.626 & 10.11 & & & \\
\hline 56 & 19 & 25 & & (a) & 5.17 & 10.68 & 10.13 & & & \\
\hline 56 & 9 & 35 & & & 5.14 & 10.64 & 10.12 & & & \\
\hline 50 & 25 & 25 & & & 5.17 & 10.60 & (c) & & & \\
\hline 45 & 45 & 10 & & & & 10.67 & (c) & & & \\
\hline 45 & 45 & 10 & & & & 10.676 & 10.12 & & & \\
\hline 45 & 40 & 21 & & & & 10.674 & 10.12 & & & \\
\hline 45 & 40 & 21 & & & & 10.706 & 10.14 & & & \\
\hline 44 & 32 & 24 & & & & 10.668 & (c) & & & \\
\hline 43 & 42 & 15 & & & 5.147 & 10.68 & 10.12 & & & \\
\hline 41 & 54 & 5 & & & & & 10.64 & (c) & & \\
\hline 40 & 40 & 20 & & & 5.15 & 10.68 & (c) & & & \\
\hline 40 & 35 & 25 & & & 5.15 & 10.66 & 10.12 & & & \\
\hline 40 & 10 & 50 & & & 5.151 & & 10.12 & & & \\
\hline 39 & 39 & 22 & & & 5.14 & 10.68 & 10.12 & & & \\
\hline
\end{tabular}


TABLE 3.2. (contd)

\begin{tabular}{|c|c|c|c|c|c|c|c|c|c|c|c|}
\hline \multirow{2}{*}{\multicolumn{3}{|c|}{ Composition, mol\% }} & \multicolumn{9}{|c|}{ Phases and Lattice Parameters, $\mathrm{nm} \times 10^{-1}$} \\
\hline & & & \multirow[b]{2}{*}{ Monoclinic } & \multirow{2}{*}{$\begin{array}{c}f c c \\
\text { Fluorite }\end{array}$} & \multirow{2}{*}{$\begin{array}{c}\text { Rhom- } \\
\text { bohedral }\end{array}$} & \multirow{2}{*}{$\begin{array}{c}f c c \\
\text { Pyrochlore }\end{array}$} & \multirow[b]{2}{*}{$\mathrm{bcc}$} & \multicolumn{3}{|c|}{ Orthorhombic } & \multirow[b]{2}{*}{$f c c$} \\
\hline $\mathrm{HfO}_{2}$ & $\mathrm{Pr}_{1.83}$ & $\mathrm{In}_{2} \mathrm{O}_{3}$ & & & & & & $\bar{a}$ & $\mathrm{~b}$ & $\mathrm{c}$ & \\
\hline 39 & 39 & 23 & & & (a) & 10.676 & (c) & & & & \\
\hline 37 & 43 & 20 & & & & 10.670 & 10.12 & & & & \\
\hline 36 & 37 & 27 & & & & 10.672 & 10.12 & & & & \\
\hline 34 & 45 & 21 & & & & 10.668 & & & & & \\
\hline 28 & 55 & 17 & & & & 10.678 & & 5.67 & 5.88 & 8.14 & \\
\hline 25 & 30 & 45 & & & & 10.66 & 10.12 & & & & \\
\hline 25 & 20 & 55 & & & & 10.64 & 10.1 & & & & \\
\hline 23 & 60 & 17 & & & & 10.696 & & 5.67 & 5.88 & 8.14 & 5.41 \\
\hline 22 & 62 & 16 & & & & 10.678 & & 5.658 & & & \\
\hline 21 & 61 & 18 & & & & 10.680 & & (d) & & & \\
\hline 20 & 50 & 30 & & & & 10.70 & (c) & (d) & & & \\
\hline 18 & 65 & 17 & & & & 10.70 & & (d) & & & \\
\hline 12 & 76 & 12 & & & & & & 5.61 & 5.86 & 8.15 & $5.41^{(e)}$ \\
\hline 10 & 82 & 8 & & & & & & 5.66 & 5.93 & 8.16 & $5.42^{(e)}$ \\
\hline 4 & 53 & 43 & & & & 10.70 & & (d) & & & \\
\hline
\end{tabular}

(a) fcc fluorite or rhombohedral phase present. Interference made resolution difficult.

(b) fcc pyrochlore phase present.

(c) bcc sesquoxide solid solution phase present.

(d) Orthrhombic phase present.

(e) $\operatorname{Pr}_{1.83}$ present reported to be cubic $10.99 \mathrm{~nm}$ or $5.4695 \mathrm{~nm}$. 
IABLE 3.3. Phases and Lattice Parameters of $\mathrm{HfO}_{2}-\mathrm{PrO}{ }_{1.83}-\mathrm{In}_{2} \mathrm{O}_{3}-\mathrm{Yb}_{2} \mathrm{O}_{3}$

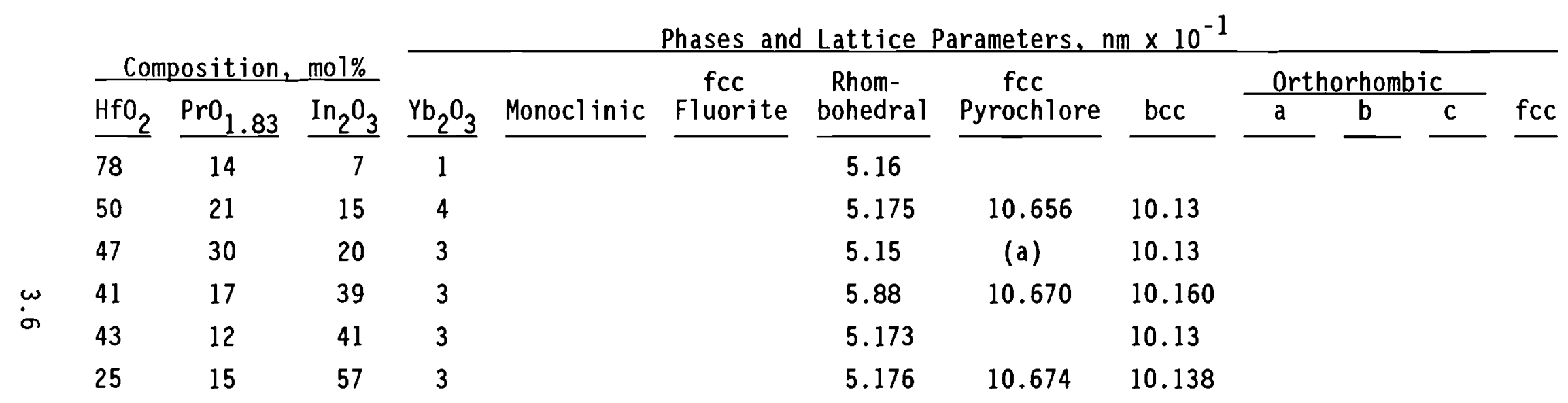

(a) fcc fluorite or rhombohedral phase present. Interference made resolution difficult. 
are analyzed and compared with standard spectra using a Traco-Northern analog system. In contrast, the XRD is accurate to $\pm 5 \%$ for most structures. However, some interference was observed for similar structures that differ only by size of unit cell required to accommodate all atoms.

The proposed $\mathrm{HfO}_{2}-\mathrm{PrO}_{2}-\mathrm{In}_{2} \mathrm{O}_{3}$ ternary phase diagram in air at $1823 \mathrm{~K}$ determined by the above procedures is shown in Figure 3.1. The diagram is first discussed in terms of the binary diagrams.

\section{$3.1 \mathrm{HfO}_{2}-\mathrm{PrO}_{1.83}$}

The $\mathrm{HfO}_{2}-\mathrm{PrO}_{1.83}$ binary relationship reported by Kravchinskaya et al. (1973) was confirmed in this study. The $\mathrm{HfO}_{2}$ is totally stabilized into a fcc fluorite structure (C) at about $24 \mathrm{mo} 1 \% \mathrm{Pr}_{1.83}$. The pyrochlore $\mathrm{Hf}_{2} \mathrm{Pr}_{2} \mathrm{O}_{7}$

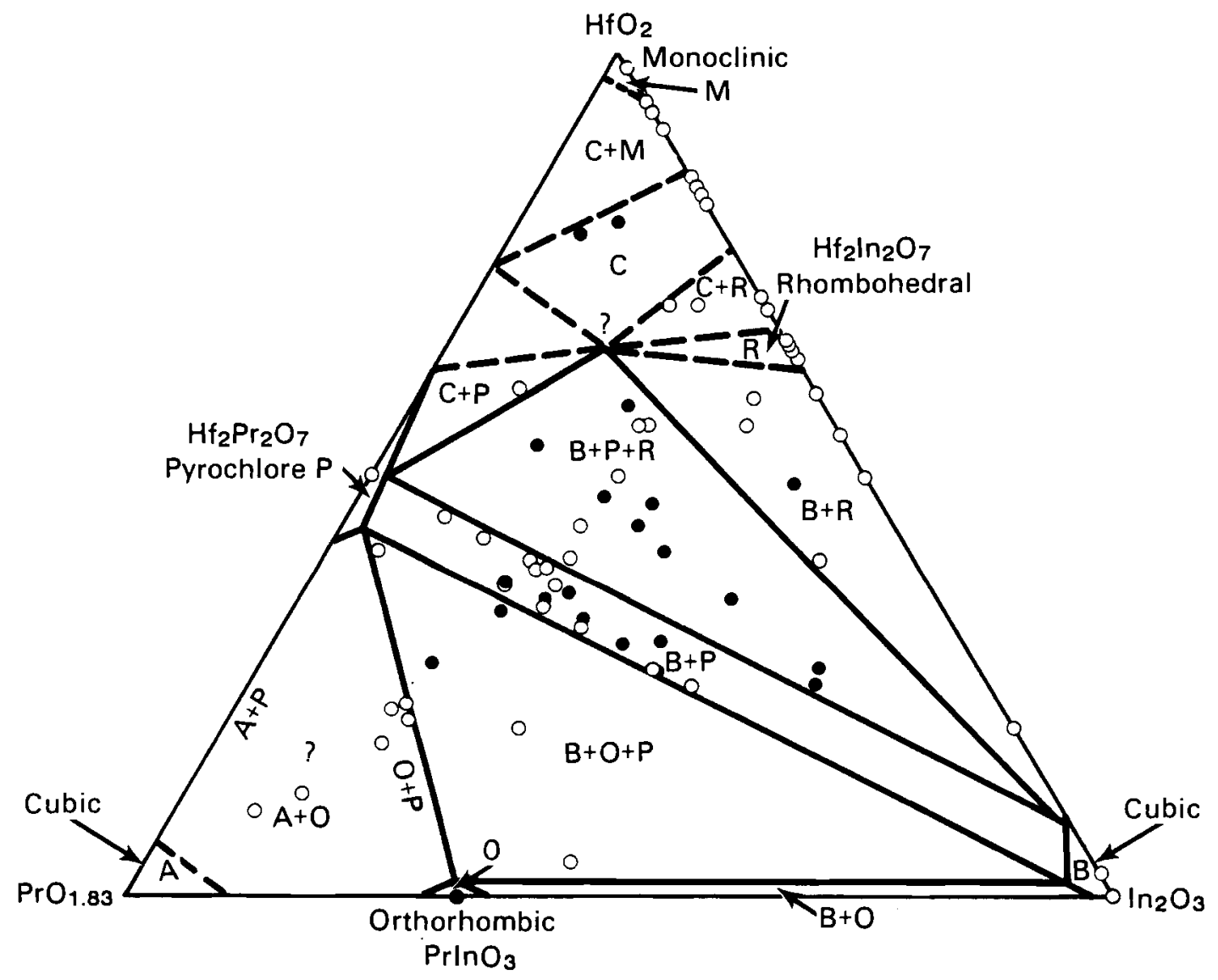

FIGURE 3.1. $\mathrm{HfO}_{2}-\operatorname{PrO}_{1.83}-\mathrm{In}_{2} \mathrm{O}_{3}$ Phase Diagram at $1812 \mathrm{~K}$ in Air 
(P) lies within the limits of 42 and $57 \mathrm{mo} \% \mathrm{PrO}_{1.83}$. The reported lattice parameter of the $\mathrm{Hf}_{2} \mathrm{Pr}_{2} \mathrm{O}_{7}$ pyrochlore is $1.0662 \pm 0.004 \mathrm{~nm}$ (Kravchinskaya et a1. 1973). This compares to a lattice parameter determined in this study that varies between 1.0664 and $1.0669 \pm 0.001 \mathrm{~nm}$ and appears relatively independent of the indium and hafnium content. The addition of In203 slightly increases the lattice parameter up to $1.070 \pm 0.001 \mathrm{~nm}$. However, this observed increase, although consistent, as shown in Table 3.1, is within the XRD measurement accuracy limits. The estimated solubility limits of $\operatorname{In}_{2} \mathrm{O}_{3}$ in the pyrochlore phase are from 1 to $3 \mathrm{~mol} \%$.

\section{$3.2 \stackrel{\operatorname{PrO}_{1.83^{-I n}} \mathrm{O}_{3}}{ }$}

An orthorhombic $\mathrm{PrInO}_{3}$ phase (0) was found in the $\mathrm{PrO}_{1.83}-\mathrm{In}_{2} \mathrm{O}_{3}$ binary with lattice parameters $a_{0}, b_{0}, c_{0}=0.567,0.593,0.818 \pm 0.01 \mathrm{~nm}$, respectively. The solubility limits are 30 to $36 \mathrm{~mol} \% \mathrm{In}_{2} \mathrm{O}_{3}$. The higher indium solubility is found at the phase boundary in the two-phase region $(0+B)$ consisting of the $\operatorname{PrInO}_{3}$ and a bcc solid solution of $\mathrm{PrO}_{1.83}$ in $\mathrm{In}_{2} \mathrm{O}_{3}$. The solubility 1 imit of $\mathrm{HfO}_{2}$ in $\mathrm{PrInO}_{3}$ is near $2 \%$. The lattice parameters at maximum $\mathrm{HfO}_{2}$ solubility in the orthorhombic $\operatorname{PrInO}_{3}$ are $\mathrm{a}_{0}=0.565, \mathrm{~b}_{0}=$ 0.589 , and $c_{0}=0.815 \pm 0.02 \mathrm{~nm}$. The solubility limit of $\mathrm{PrO}_{1.83}$ is about 2 to $3 \mathrm{~mol} \%$. The lattice parameters at maximum solubility are 1.0188 $\pm 0.0005 \mathrm{~nm}$ compared with a measured value of $1.0118 \pm 0.001 \mathrm{~nm}$ for pure $\mathrm{In}_{2} \mathrm{O}_{3}$.

The solubility limit of $\mathrm{In}_{2} \mathrm{O}_{3}$ in $\mathrm{Pr}_{1.83}$ is between 7 and $10 \mathrm{~mol} \%$ with a lattice parameter of $0.546 \mathrm{~nm}$ at maximum solubility compared to $0.547 \mathrm{~nm}$ for $\mathrm{PrO}_{1.83}$. This is in excellent agreement with crystallographic data reported by Swanson et al. (1953), which indicates a cubic lattice with unit cell of $0.54695 \mathrm{~nm}$. However, Aleshin and Roy (1962) reported a cubic pyrochlore structure with a $1.099 \mathrm{~nm}$ (doubled) unit cell. The ionic radius of $\mathrm{In}^{+3}$ $(0.08 \mathrm{~nm})$ is smaller than that for $\operatorname{Pr}^{+4}(0.090 \mathrm{~nm})$. Consequently, the lattice parameter changes may be smaller depending upon the defect formation required for charge compensation due to different valence states.

The stable cubic $\operatorname{Pr}_{1.83}$ or $\operatorname{Pr}_{6} \mathrm{O}_{11}$ phase appears to be converted to a fcc structure with additions of $\mathrm{HfO}_{2}$ and/or $\mathrm{In}_{2} \mathrm{O}_{3}$. The lattice parameter of this unit cell determined in the two-phase field containing orthorhombic and 
fcc is near $0.541 \mathrm{~nm}$ as shown in Table 3.1b. This may be related to a transition from an oxygen deficient to a stoichiometric, oxygen fluorite phase as reported by Brauer and Willaredt (1980). Such a fcc phase was not reported by Kravchinskaya et al. (1973) for $\mathrm{HfO}_{2}$ additions alone.

\section{$3.3 \mathrm{HfO}_{2}-\mathrm{In}_{2} \mathrm{O}_{3}$}

The $\mathrm{HfO}_{2}$ is also stabilized as a fcc phase (c) with 10 to 24 mol\% $\operatorname{In}_{2} \mathrm{O}_{3}$. The fcc lattice parameter of $0.511 \mathrm{~nm}$ decreases nearly linearly with increasing $\operatorname{In}_{2} \mathrm{O}_{3}$ content according to the expression

$$
a_{0}=5.1116-0.09285\left(\mathrm{~mol}_{\%} \operatorname{In}_{2} \mathrm{O}_{3}\right)
$$

reaching a value of $0.508 \mathrm{~nm}$ at $35 \mathrm{~mol} \% \mathrm{In}_{2} \mathrm{O}_{3}$. Between 24 and $35 \mathrm{~mol} \% \mathrm{In}_{2} \mathrm{O}_{3}$, the fcc lattice appears to exist with a closely related rhombohedral $\mathrm{Hf}_{2} \mathrm{In}_{2} \mathrm{O}_{7}$ phase, which is described later. Scatter in the lattice parameter data is observed below $10 \mathrm{~mol} \% \mathrm{In}_{2} \mathrm{O}_{3}$ and appears to be related to the presence of the monoclinic $\mathrm{HfO}_{2}$ phase, which coexists with the fcc fluorite phase at room temperature.

A rhombohedral $\mathrm{Hf}_{2} \mathrm{In}_{2} \mathrm{O}_{7}$ phase (R) was formed in the $\mathrm{HfO}_{2}-\mathrm{In}_{2} \mathrm{O}_{3}$ binary. This phase has a lattice parameter of $a_{0}=0.517 \mathrm{~nm}$ and alpha $=90.4$ degrees. This very small deviation in alpha from the 90 degrees for the $\operatorname{In}_{2} \mathrm{O}_{3}$-stabilized $\mathrm{HfO}_{2}$ suggests this rhombohedral phase may result from an anisotropic ordering of the fcc phase. The nominal $\mathrm{Hf}_{2} \mathrm{In}_{2} \mathrm{O}_{7}$ composition determined by EDX was $35 \mathrm{~mol}^{\%} \mathrm{In}_{2} \mathrm{O}_{3}$ and $65 \mathrm{~mol}^{\circ} \mathrm{HfO}_{2}$.

The close similarity between the fcc $\operatorname{In}_{2} \mathrm{O}_{3}$ and/or the $\mathrm{In}_{2} \mathrm{O}_{3}+\mathrm{PrO}_{1.83}$ stabilized $\mathrm{HfO}_{2}$ and the rhomohedral $\mathrm{Hf}_{2} \mathrm{In}_{2} \mathrm{O}_{7}$ structure made it difficult to distinguish by $x$-ray diffraction the two phases when both were present. However, the nearly linear decrease in the lattice parameter for the fcc $\mathrm{In}_{2} \mathrm{O}_{3}$ stabilized $\mathrm{HfO}_{2}$ to $0.508 \mathrm{~nm}$ at $35 \mathrm{~mol} \% \mathrm{In}_{2} \mathrm{O}_{3}$ and the larger value of the rhombohedral structure of 0.514 to $0.517 \mathrm{~nm}$ suggest different structures. These two phases were also observed in some instances in a two-phase field containing another phase. This, coupled with the presence of the fcc pyrochlore $\mathrm{Hf}_{2} \mathrm{In}_{2} \mathrm{O}_{7}$ which has a lattice parameter of 1.066 to $1.070 \mathrm{~nm}$, makes 
a resolution of the $\mathrm{HfO}_{2}-\mathrm{PrO}_{1.83}-\mathrm{In}_{2} \mathrm{O}_{3}$ ternary diagram with high $\mathrm{HfO}_{2}$ very complex. (A doubling of a 0.533 to $0.535-\mathrm{nm}$-unit cell is required to account for the extra atoms in the cel1.) Further studies of this area are required.

Saito, Maruyama, and Kato (1983), did not report observing the rhombohedral phase; however, they fabricated samples by sintering admixtures of $\mathrm{HfO}_{2}$ and $\mathrm{In}_{2} \mathrm{O}_{3}$ powders. Similar results were observed by Glushkova and Krzhizkanovskaya (1973). This may have inhibited the formation of the rhombohedral phase. Experiments during this study indicate that the reaction between mixed powders of $\mathrm{In}_{2} \mathrm{O}_{3}$ and $\mathrm{HfO}_{2}$ is incomplete, with the formation of an $\mathrm{In}_{2} \mathrm{O}_{3}$ solid solution with $\mathrm{HfO}_{2}$ surrounding the $\mathrm{HfO}_{2}$ crystallites. This conclusion is reinforced by the electrical conductivity data, as discussed later.

The $\mathrm{In}_{2} \mathrm{O}_{3}$ forms a solid solution with $\mathrm{HfO}_{2}$ with a rare-earth, B-type, sesquioxide structure (B). The maximum solubility of $\mathrm{HfO}_{2}$ was not determined accurately, but appears to be near $10 \mathrm{~mol} \%$ with a lattice parameter near $1.012 \pm 0.001 \mathrm{~nm}$. The bcc $\mathrm{In}_{2} \mathrm{O}_{3}$ forms a solid solution with both $\mathrm{HfO}_{2}$ and $\mathrm{PrO}_{1.83}$. However, the definition of combined $\mathrm{HfO}_{2}$ plus $\mathrm{PrO}_{1.83}$ solubility 7 imits was very difficult because the vortices of 2 three-phase fields and 3 two-phase fields converge between 90 and $95 \mathrm{~mol}_{2} \mathrm{In}_{2} \mathrm{O}_{3}$.

\section{$3.4 \mathrm{HfO}_{2}-\mathrm{PrO}_{1.83}-\mathrm{In}_{2} \mathrm{O}_{3}$}

The major portion of the ternary phase diagram is made up of two fields containing three phases; i.e., $(0+P+B)$ and $(R+P+B)$. These two fields are separated by a two-phase $(P+B)$ field. Because of the interest in high electrically conducting phases and similar thermal properties to stabilized $\mathrm{HfO}_{2}\left(\mathrm{ZrO}_{2}\right)$, the phase diagram results were concentrated in the high- $\mathrm{HfO}_{2}$ portion of the ternary diagram, between $\mathrm{Hf}_{2} \mathrm{Pr}_{2} \mathrm{O}_{7}, \mathrm{fcc} \mathrm{HfO}_{2}$, and bcc $\mathrm{In}_{2} \mathrm{O}_{3}$ solid solution. Regions high in $\mathrm{Pr}_{1.83}$ remain to be defined.

The $\mathrm{Hf}_{2} \mathrm{In}_{2} \mathrm{O}_{7}$ rhombohedral phase appears to be stabilized with additions of $\mathrm{PrO}_{1.83}$. However, because of the similarity in diffraction patterns to the fcc fluorite phase and the small size of this phase, the resolution and composition limits of the rhombohedral phase in the ternary were difficult to 
determine quantitatively with EDX. Additions of a few mol\% of $\mathrm{Yb}_{2} \mathrm{O}_{3}$ to the

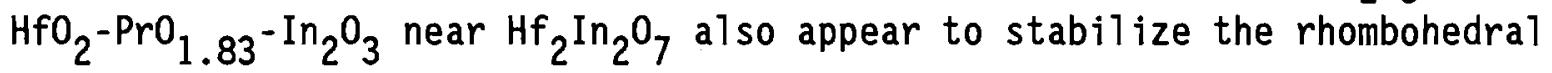
phase. 



\subsection{ELECTRICAL TRANSPORT PROPERTIES}

The understanding of the electrical transport properties is critical to selecting compositions, improving properties and structures, and evaluating the performance of materials for solid oxide fuel cells. The dc electrical conductivity, Seebeck coefficients, and transference numbers were measured and related to the $\mathrm{HfO}_{2}-\mathrm{PrO}_{1.83}-\mathrm{In}_{2} \mathrm{O}_{3}$ phase equilibria to determine the electrical transport characteristics of the various structures and phases.

\subsection{ELECTRICAL CONDUCTIVITY}

The electrical conductivity $(\sigma)$ was measured to $1700 \mathrm{~K}$ in air using a four-point probe method. The rectangular bars, which were $3 \mathrm{~cm} 1$ ong and $-0.1 \mathrm{~cm}^{2}$, were placed in a Pt knife-edge holder. Direct current was passed through the sample using knife edges placed near the contact area at the end of the sample bar, which was coated with Pt paste to reduce contact resistances. The electric potential along the sample was measured using knife edges set at predetermined distances on the sample side opposite the current leads. A voltmeter with an internal impedance greater than 10 megohms was used to measure the voltages and a microammeter was used to measure the current. Measurements of voltages across standard resistors in parallel with the sample current were also used to verify sample resistances. The direct current densities did not exceed $0.05 \mathrm{~A} / \mathrm{cm}^{2}$. Measurements were accurate to within $\pm 10 \%$. Samples temperatures were measured with calibrated Pt-Pt10Rh thermocouples referenced to the gold melting point. Temperatures were controlled to within \pm 1 degree Kelvin.

One or more $l$ inear $\log \sigma$ versus $1 / \mathrm{K}$ relations were fitted to the data. The coefficients of determination were generally greater than 0.98 at high temperatures and greater than 0.95 at low temperatures.

The electrical conductivities of compositions in the $\mathrm{HfO}_{2}-\mathrm{PrO}_{1.83}-\mathrm{In}_{2} \mathrm{O}_{3}$ were measured to determine the phase fields and phases that exhibited the highest electrical conductivity. Results for compositions in the $\mathrm{HfO}_{2}-\mathrm{In}_{2} \mathrm{O}_{3}$ binary and the center of the $\mathrm{HfO}_{2}-\mathrm{PrO}_{1.83} \mathrm{In}_{2} \mathrm{O}_{3}$ ternary were emphasized. 


\section{$4.1 .1 \mathrm{HfO}_{2}-\mathrm{In}_{2} \mathrm{O}_{3}$}

The $\mathrm{HfO}_{2}-\mathrm{In}_{2} \mathrm{O}_{3}$ system was studied initially because of the high conductivity of the bcc $\mathrm{In}_{2} \mathrm{O}_{3}$ solid solution and the similarity of the $\mathrm{In}_{2} \mathrm{O}_{3}$ stabilized $\mathrm{HfO}_{2}$ with the $\mathrm{Y}_{2} \mathrm{O}_{3}$-stabilized $\mathrm{ZrO2}$ solid solution. It is essentially a binary of the $\mathrm{HfO}_{2}-\mathrm{PrO}_{1.83}-\mathrm{In}_{2} \mathrm{O}_{3}$ ternary system. The electrical conductivity results are shown in Figure 4.1 and summarized in Table 4.1 for compositions containing between 17 and $40 \mathrm{~mol} \% \mathrm{In}_{2} \mathrm{O}_{3}$. The conductivity decreased with increasing $\mathrm{In}_{2} \mathrm{O}_{3}$ reaching a minimum value of $5 \times 10^{-1}$ (ohm$\mathrm{cm})^{-1}$ at $1273 \mathrm{~K}$ near $40 \mathrm{mo} \%$, which corresponds approximately to the $\mathrm{Hf}_{2} \mathrm{In}_{2} \mathrm{O}_{7}$ rhombohedral composition. The conductivity then increased rapidly between 40 and $50 \mathrm{~mol} \%$; this increase is attributed to the increase in the bcc $\operatorname{In}_{2} \mathrm{O}_{3}$ solid solution phase. The conductivity should continue to increase with increasing $\mathrm{In}_{2} \mathrm{O}_{3}$ content as the bcc $\mathrm{In}_{2} \mathrm{O}_{3}$ solid solution increases in this

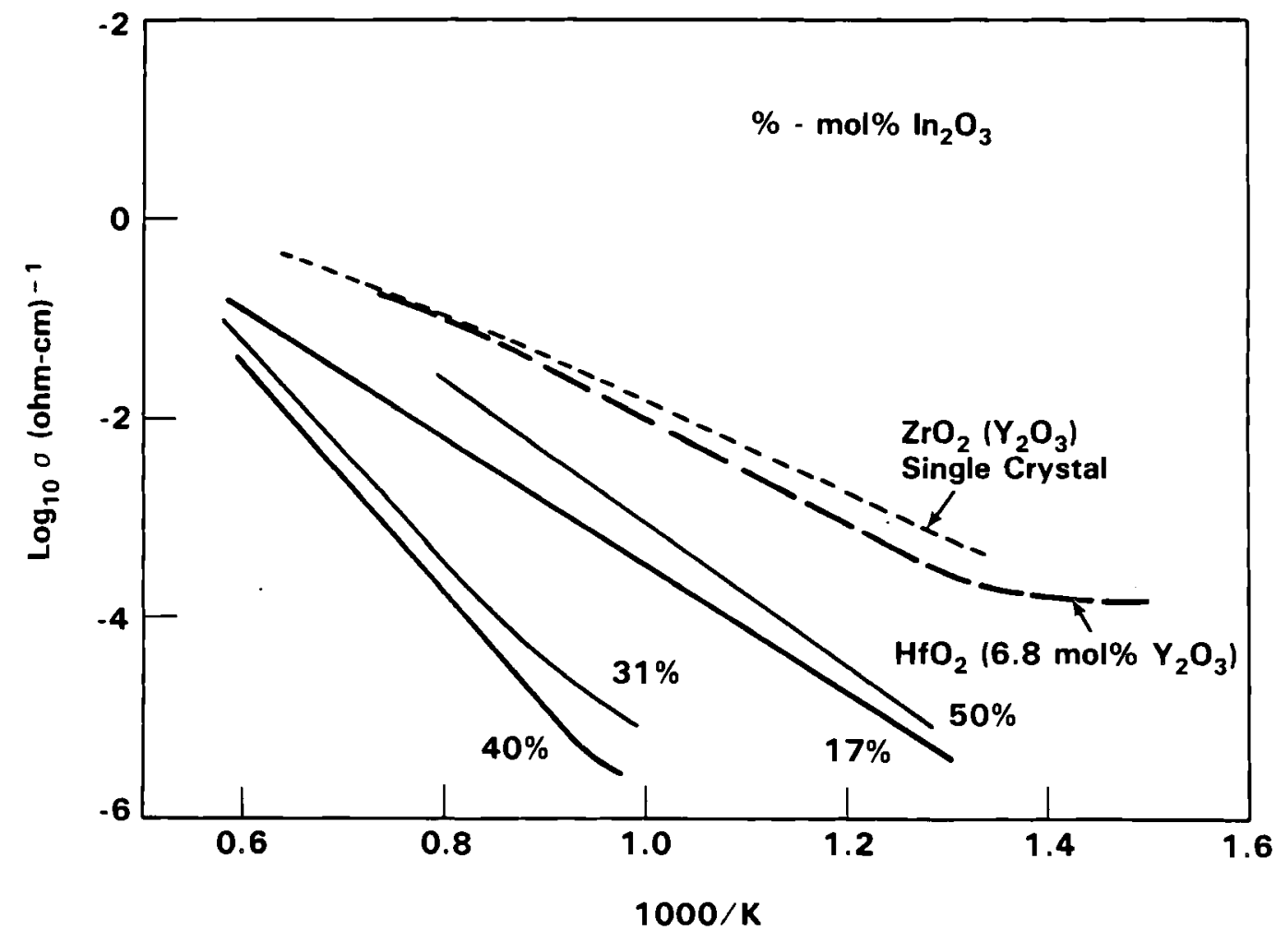

FIGURE 4.1. Electrical Conductivity for $\mathrm{HfO}_{2}-\mathrm{In}_{2} \mathrm{O}_{3}, \mathrm{ZrO}_{2}\left(\mathrm{Y}_{2} \mathrm{O}_{3}\right)$ Single Crystal and $\mathrm{HfO}_{2}\left(\mathrm{Y}_{2} \mathrm{O}_{3}\right)$ 
TABLE 4.1. Composition and Electrical Conductivity of $\mathrm{HfO}_{2}-\mathrm{In}_{2} \mathrm{O}_{3}$

\begin{tabular}{|c|c|c|c|c|c|c|c|}
\hline & \multicolumn{2}{|c|}{$\begin{array}{c}\text { Composition } \\
\text { mol\% }\end{array}$} & \multicolumn{2}{|c|}{$\log _{10}(a)=A-B K^{-1}$} & \multirow{2}{*}{$\begin{array}{l}\text { Temperature } \\
\text { Range, } \mathrm{K} \\
\end{array}$} & \multirow{2}{*}{$\begin{array}{l}\text { Activation } \\
\text { Energy, eV }\end{array}$} & \multirow{2}{*}{$\begin{array}{l}\text { Coefficient } \\
\text { Determination, } \\
\mathrm{R}^{2} \\
\end{array}$} \\
\hline Sample & $\overline{\mathrm{HfO}_{2}}$ & $\mathrm{In}_{2} \mathrm{O}_{3}$ & $A$ & B & & & \\
\hline FC-13-3 & 0 & 100 & 1.752 & $-0.1560^{(b)}$ & $397-1631$ & -- & 0.890 \\
\hline FC-53 & 69 & 31 & 4.238 & 9.423 & $994-1719$ & 1.87 & 0.980 \\
\hline FC-14-1 & 60 & 40 & 5.465 & 11.54 & $986-1655$ & 2.29 & 0.999 \\
\hline$F C-52$ & 50 & 50 & 2.521 & 5970 & $668-1731$ & 1.19 & 0.980 \\
\hline FC-54-1 & 83 & 17 & 3.422 & 6419 & $657-1726$ & 1.27 & 0.985 \\
\hline
\end{tabular}

(a) $(\mathrm{ohm}-\mathrm{cm})^{-1}$.

(b) Slope is positive. 
two-phase region, reaching values greater than those for pure $\mathrm{In}_{2} \mathrm{O}_{3}$, greater than $10^{2}(\mathrm{ohm}-\mathrm{cm})^{-1}$. It has been reported by Bates et al. (1986) that additions of oxides, such as $\mathrm{SnO}_{2}$, increase significantly the conductivity of pure $\mathrm{In}_{2} \mathrm{O}_{3}$ oxide, reaching a maximum at the maximum solutibility of $\mathrm{SnO}_{2}$. The electrical conductivity of the 17 mol\% In $_{2} \mathrm{O}_{3}$ with the fcc structure is only slightly lower than the conductivity for the $10 \mathrm{~mol} \% \mathrm{Y}_{2} \mathrm{O}_{3}$-stabilized $\mathrm{HfO}_{2}$ or $\mathrm{ZrO}_{2}$. The extrapolation of the electrical conductivity data for 10 mol\% $\mathrm{In}_{2} \mathrm{O}_{3}$ in $\mathrm{HfO}_{2}$ suggests conductivity values near that for $\mathrm{Y}_{2} \mathrm{O}_{3}$-stabilized $\mathrm{HfO}_{2}$ and $\mathrm{ZrO}_{2}$. Thus $\mathrm{In}_{2} \mathrm{O}_{3}$ appeared to be effective in the fcc stabilization of $\mathrm{HfO}_{2}$.

Saito et a1. (1983) reported electrical conductivity values for 20 to $30 \mathrm{~mol} \% \mathrm{In}_{2} \mathrm{O}_{3}$ in $\mathrm{HfO}_{2}, 5$ to 50 times higher than those of the present study, and a decrease in conductivity with increasing mol\% $\mathrm{In}_{2} \mathrm{O}_{3}$. The activation energy was reported to be a nearly constant value of $1.7 \mathrm{eV}$ over this composition range; in this study, the activation energies vary from 1.2 to $2.3 \mathrm{eV}$, as shown in Figure 4.2. These differences are attributed to the differences in the fabrication methods. Saito, Maruyama, and Kato (1983) sintered admixtures of $\mathrm{HfO}_{2}$ and $\mathrm{In}_{2} \mathrm{O}_{3}$ powders which could have resulted in inhomogeneous structures and the presence of the bcc $\operatorname{In}_{2} \mathrm{O}_{3}$ solid solution phase at lower $\mathrm{In}_{2} \mathrm{O}_{3}$ content. It could also have inhibited the formation of rhombohedral $\mathrm{Hf}_{2} \mathrm{In}_{2} \mathrm{O}_{7}$ phase during sintering. The formation of the bcc phase could result in higher electrical conductivities.

Plotkin, Plyushcev, and Rozdin (1976) also measured the electrical conductivity of $\mathrm{HfO}_{2}-\mathrm{In}_{2} \mathrm{O}_{3}$ at 90 and $293 \mathrm{~K}$. The conductivities increased with increasing $\mathrm{In}_{2} \mathrm{O}_{3}$ and, at $293 \mathrm{~K}$, the values ranged from 0.4 to 5 (ohm-cm $)^{-1}$. These values were lower than those reported here. Like the oxides described in Saito, Maruyama, and Kato (1983), the oxides were fabricated from admixed powders. The powders were calcined at $1200 \mathrm{~K}$ for 48 hours followed by sintering at 1450 to $1500 \mathrm{~K}$ for 4 hours. Thus, the conducting phase appears to be the $\operatorname{In}_{2} \mathrm{O}_{3}$ solid solution surface coating between grains. 


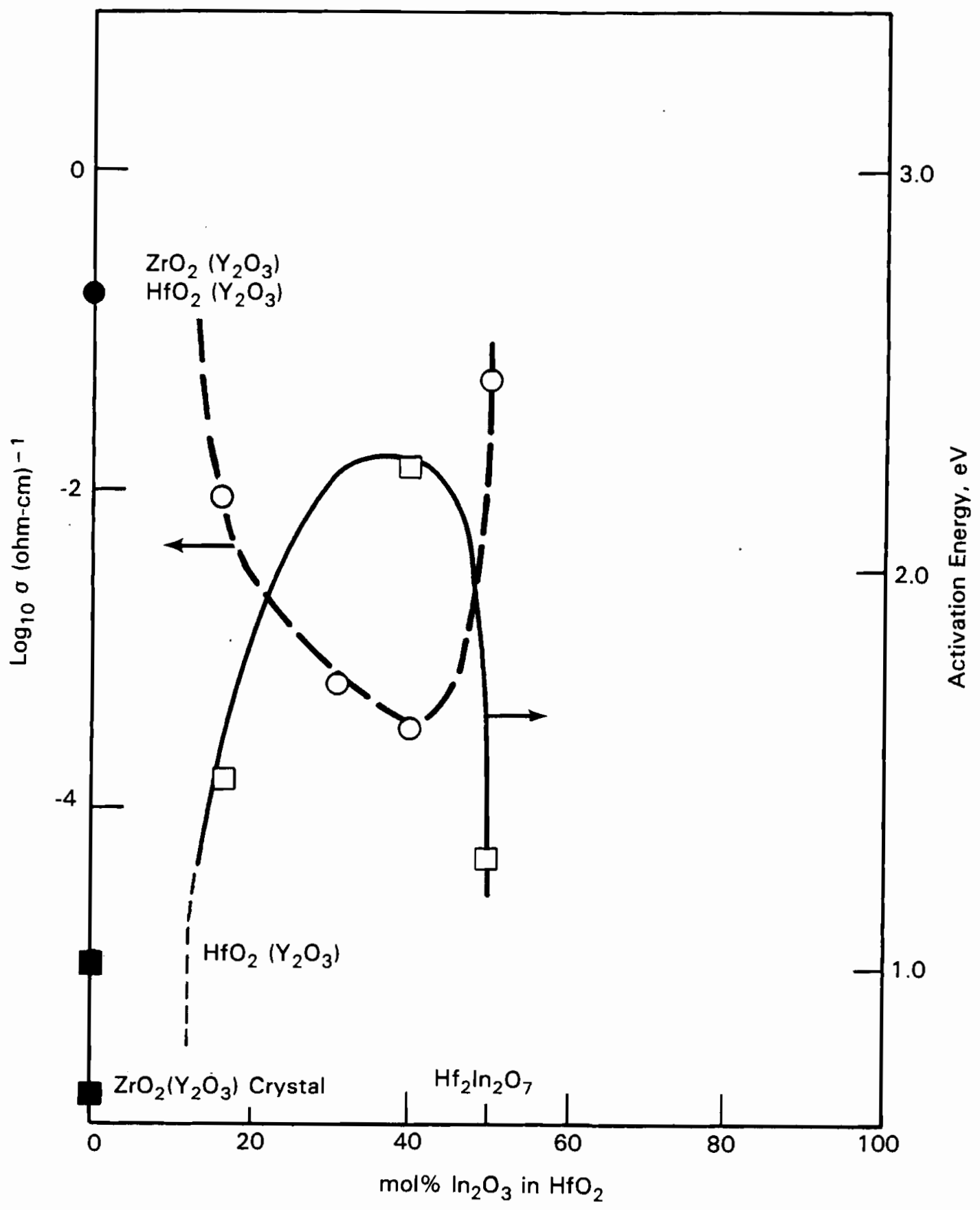

FIGURE 4.2. Activation Energy and Electrical Conductivity at $1000 \mathrm{~K}$ of $\mathrm{HfO}_{2}-\mathrm{In}_{2} \mathrm{O}_{3}$ as a Function of mol\% $\mathrm{In}_{2} \mathrm{O}_{3}$ 


\section{$4.1 .2 \mathrm{HfO}_{2}-\mathrm{PrO}_{1.83}-\mathrm{In}_{2} \mathrm{O}_{3}$}

The electrical conductivities of compositions in the center of the $\mathrm{HfO}_{2}$ $\mathrm{PrO}_{2}-\mathrm{In}_{2} \mathrm{O}_{3}$ ternary were measured to determine the phase fields, structures, and phases which exhibit the highest electrical conductivity. The compositions, structures, and electrical conductivity results are summarized in Tables 4.2 and 4.3 and in Figure 4.3. These results also include samples with similar compositions containing small amounts of $\mathrm{Yb}_{2} \mathrm{O}_{3}$. (Those compositions containing some $\mathrm{Yb}_{2} \mathrm{O}_{3}$ are shown as solid data points on the phase diagram for the $\mathrm{HfO}_{2}-\mathrm{PrO}_{2}-\mathrm{In}_{2} \mathrm{O}_{3}$ system in Figure 3.1. The $\mathrm{Yb}_{2} \mathrm{O}_{3}$ was considered to be similar to the $\operatorname{PrO}_{1.83}$ and, for consistency, was added to the $\mathrm{PrO}_{1.83}$ content.)

The electrical conductivity of the major phases in the $\mathrm{HfO}_{2}-\mathrm{PrO}_{1.83^{-}}$ $\mathrm{In}_{2} \mathrm{O}_{3}$ system was determined as a base for further study of the two- and three-phase structures in this system. The results for $\mathrm{Hf}_{2} \mathrm{In}_{2} \mathrm{O}_{7}$ were discussed previously. The electrical conductivity of the orthorhombic $\mathrm{PrInO}_{3}$ and the pyrochlore $\mathrm{Hf}_{2} \mathrm{Pr}_{2} \mathrm{O}_{7}$ are low, with values between $10^{-3}$ and $10^{-4}(\mathrm{ohm}-\mathrm{cm})^{-1}$ at $1273 \mathrm{~K}$ with a high temperature dependence. The electrical conductivity of the monoclinic $\mathrm{HfO}_{2}$ is even lower, $10^{-4}$ to $10^{-5}(\mathrm{ohm}-\mathrm{cm})^{-1}$, at $1273 \mathrm{~K}$.

The electrical conductivities increase with increasing $\operatorname{In}_{2} \mathrm{O}_{3}$ content and approach maximum conductivities at all temperatures above $40 \mathrm{~mol} \% \mathrm{In}_{2} \mathrm{O}_{3}$. Figure 4.4 shows the conductivities at 923,1273 , and $1667 \mathrm{~K}$. This general composition dependence is found in both the two- and three-phase fields containing $\mathrm{Hf}_{2} \mathrm{In}_{2} \mathrm{O}_{7}$ and/or $\mathrm{Hf}_{2} \mathrm{In}_{2} \mathrm{O}_{7}$ but with the cubic $\mathrm{In}_{2} \mathrm{O}_{3}$ solid solution. Thus, it is concluded that the major conducting phase is the $\operatorname{In}_{2} \mathrm{O}_{3}$ solid solution.

Using XRD data coupled with the ternary phase diagram in Figure 3.1 , the concentrations of the $\mathrm{In}_{2} \mathrm{O}_{3}$ bcc $\mathrm{In}_{2} \mathrm{O}_{3}$ solid solution were determined for each of the $\mathrm{HfO}_{2}-\mathrm{PrO}_{1.83}-\mathrm{In}_{2} \mathrm{O}_{3}$ compositions. The logarithms of the electrical conductivity at $1273 \mathrm{~K}$ were compared as a function of bcc $\mathrm{In}_{2} \mathrm{O}_{3}$ solid solution and of total content. These results show a nearly linear increase up to $30 \mathrm{~mol} \%$, Figures $4.5 \mathrm{a}$ and $4.5 \mathrm{~b}$. At higher concentrations, the data exhibit more scatter but appear to reach a near constant value for each 
TABLE 4.2. Composition and Electrical Conductivity of $\mathrm{HfO}_{2}-\mathrm{PrO}_{1.83}-\mathrm{In}_{2} \mathrm{O}_{3}-\mathrm{Yb}_{2} \mathrm{O}_{3}$

\begin{tabular}{|c|c|c|c|c|c|c|c|c|c|c|c|c|c|c|c|}
\hline \multirow[b]{3}{*}{ Sample } & \multirow{2}{*}{\multicolumn{4}{|c|}{ Composition, mol\% }} & \multirow{2}{*}{\multicolumn{3}{|c|}{ Structure, $\operatorname{mol} \%(a, b)$}} & \multicolumn{8}{|c|}{ Electrical Conductivity (ohm-cm) ${ }^{-1}$} \\
\hline & & & & & & & & \multicolumn{4}{|c|}{ High Temperature } & \multicolumn{4}{|c|}{ Low Temperature } \\
\hline & $\mathrm{HfO}_{2}$ & $\ln _{3} \mathrm{O}_{3}$ & $\mathrm{PrO}_{1,83}$ & $\mathrm{Yb}_{2} \mathrm{O}_{3}$ & B & $\mathbf{P}$ & $\mathbf{R}$ & $A$ & $B\left(10^{3}\right)$ & ev & $k$ & $A$ & $B\left(10^{2}\right)$ & eV & K \\
\hline \multirow[t]{2}{*}{ AP } & 78 & 7 & 14 & 1 & 10 & 90 & -- & 2.507 & 5.400 & 1.07 & $1087-1679$ & & & & \\
\hline & & & & & & & & 3.679 & 6.907 & 1.37 & $978-1651$ & & & & (c) \\
\hline$A Q$ & 63 & 2 & 34 & 4 & - & 50 & 50 & 2.076 & 6.317 & 1.25 & $1157-1706$ & & & & (c) \\
\hline AC & 54 & 26 & 16 & 4 & 10 & 40 & 50 & 2.241 & 4.895 & 0.97 & $1212-1716$ & & & & (c) \\
\hline AF & 57 & 15 & 24 & 4 & 10 & 25 & 60 & 4.378 & 9.695 & 1.93 & $1324-1503$ & -0.5501 & 3596 & 0.71 & $791-1242$ \\
\hline$A G$ & & & & & 15 & 25 & 60 & & & & & & & & \\
\hline LLL & 47 & 30 & 20 & 3 & 30 & 15 & 65 & 3.273 & 2.840 & 0.56 & $997-1508$ & 1.516 & 9953 & 0.198 & $646-997^{(d)}$ \\
\hline KKK & 41 & 39 & 17 & 3 & 30 & 20 & 50 & 4.496 & 3.120 & 0.620 & $950-1491$ & 2.045 & 7773 & 0.15 & $612-950^{(d)}$ \\
\hline \multirow[t]{2}{*}{ FC-1 } & 37 & 25 & 38 & - & 25 & $\sqrt{5}$ & 0 & 2.740 & 1.996 & 0.40 & $287-1073^{(d)}$ & 1.01 & & & \\
\hline & & & & & & & & 4.049 & 4.162 & 0.83 & $1100-1782^{(e)}$ & 1.408 & 1156 & 0.23 & $421-1050$ \\
\hline \multirow[t]{2}{*}{$\mathrm{FC}-2$} & 37 & 25 & 38 & -- & 25 & $\sqrt{5}$ & 0 & 4.718 & 5.382 & 1.07 & $1100-164^{(d)}$ & 1.175 & 1395 & 8.28 & $420-1075$ \\
\hline & & & & & & & & 2.341 & 1.502 & 0.30 & $838-1644^{(e)}$ & & & & \\
\hline AO & 28 & 54 & 15 & 3 & 50 & 20 & 30 & 1.878 & 2.783 & 0.55 & $987-1647$ & 1.138 & 2.544 & 0.05 & $335-930$ \\
\hline AS & 35 & 40 & 21 & 4 & 50 & 40 & 10 & 2.178 & 1.328 & 0.26 & $1135-1688$ & 0.989 & 0.248 & 0.05 & $710-1046$ \\
\hline AG & 50 & 25 & 21 & 4 & 15 & 25 & 60 & 0.956 & 3.178 & 0.63 & $930-1725$ & 0.440 & 8.118 & 0.16 & $643-930$ \\
\hline \multirow[t]{2}{*}{$B 4$} & 25 & 55 & 20 & -- & $E^{(t)}$ & $E^{(t)}$ & -- & 3.160 & 1.904 & 0.30 & $895-1651^{(d)}$ & 2.188 & 1051 & 0.20 & $697-895^{(d)}$ \\
\hline & & & & & & & & & & & & 0.8052 & 8240 & 0.16 & $398-697^{(e)}$ \\
\hline B5 & & & & & & & & 3.206 & 1.927 & 0.38 & $898-1649^{(d)}$ & & & & (c) \\
\hline \multirow[t]{2}{*}{ BB } & 25 & 45 & 30 & -- & 45 & 55 & -- & 3.462 & 1.970 & 0.39 & $800-1434$ & 2.1278 & 8811 & 0.18 & $562-763$ \\
\hline & & & & & & & & & & & & 1.005 & 2498 & 0.05 & $299-562$ \\
\hline$A B$ & 29 & 51 & 12 & 3 & 50 & 10 & 40 & 4.66 & 3.846 & 0.764 & $1116-1783$ & 1.660 & 4.425 & 0.09 & $512-1141$ \\
\hline
\end{tabular}

(a) $B=$ bcc; $P=$ Pyrochlore; $R=$ Rhombohedral.

(b) Weight percent determined by $X$-ray diffraction - $\pm 5 \%$.

(c) Data irregular at low temperatures; e.g., high scatter at room temperature.

(d) Difference on heating and cooling.

(e) Decreasing temperature.

(f) Phase present. 
TABLE 4.3. Compositions of $(1-\mathrm{x})\left(0.277 \mathrm{HfO}_{2} \cdot 0.63 \mathrm{PrO}_{1.83} \cdot 0.10 \mathrm{Yb}_{2} \mathrm{O}_{3}\right) \cdot \times \mathrm{In}_{2} \mathrm{O}_{3}$
$A F-1$
$0.85\left(0.27 \mathrm{PrO}_{2} \cdot 0.63 \mathrm{HfO}_{2} \cdot 0.10 \mathrm{YbO1} .5\right) \cdot 0.15 \mathrm{In}_{2} \mathrm{O}_{3}$
$A G-1$
$0.75\left(0.27 \mathrm{PrO}_{2} \cdot 0.63 \mathrm{HfO}_{2} \cdot 0.10 \mathrm{YbO1.5}\right) \cdot 0.25 \mathrm{In}_{2} \mathrm{O}_{3}$
LLL
$0.70\left(0.27 \mathrm{PrO}_{2} \cdot 0.64 \mathrm{HfO}_{2} \cdot 0.09 \mathrm{YbO1} .5\right) \cdot 0.30 \mathrm{In}_{2} \mathrm{O}_{3}$
$A B-1$
$0.43\left(0.27 \mathrm{PrO}_{2} \cdot 0.63 \mathrm{HfO}_{2} \cdot 0.10 \mathrm{YbO1.5}\right) \cdot 0.57 \mathrm{In}_{2} \mathrm{O}_{3}$
$\mathrm{BB}$

$$
0.55\left(0.55 \mathrm{PrO}_{2} \cdot 0.45 \mathrm{HfO}_{2} \cdot 0.45 \mathrm{In}_{2} \mathrm{O}_{3}\right)
$$
KKK

$$
0.61\left(0.27 \mathrm{PrO}_{2} \cdot 0.64 \mathrm{HfO}_{2} \cdot 0.09 \mathrm{YbO1.5}\right) \cdot 0.39 \mathrm{In}_{2} \mathrm{O}_{3}
$$

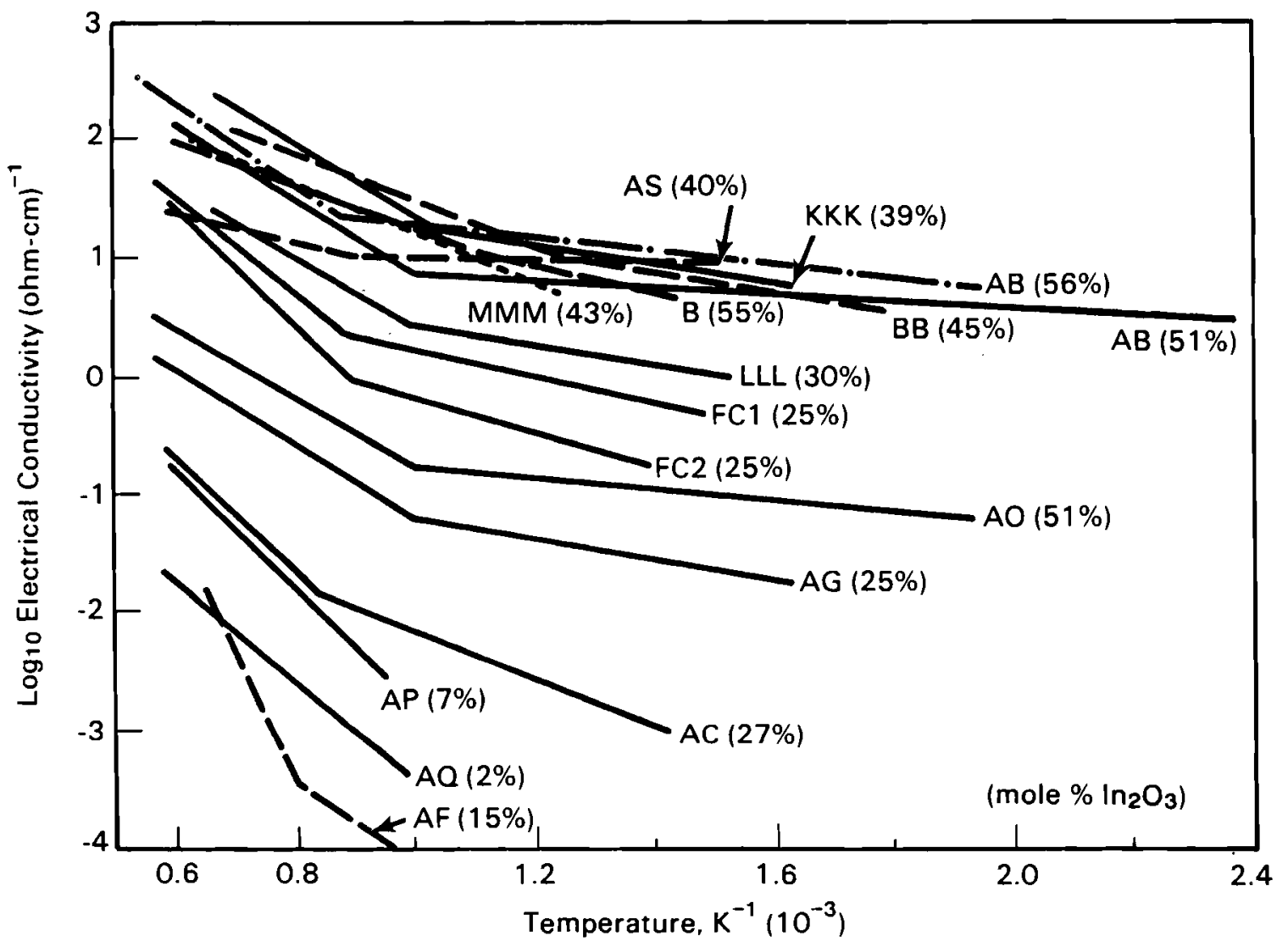

FIGURE 4.3. Electrical Conductivity of $\mathrm{HfO}_{2}-\mathrm{PrO}_{1.83}-\mathrm{In}_{2} \mathrm{O}_{3}$, Including Some with a Small Percentage of $\mathrm{Yb}_{2} \mathrm{O}_{3}$

temperature, up to 60 mol\% bcc solid solution. There is significantly less scatter in data when the $\mathrm{In}_{2} \mathrm{O}_{3}$ solid-solution content rather than the total content $\mathrm{In}_{2} \mathrm{O}_{3}$ is plotted against the electrical conductivities. The activation energies for these compositions also exhibit significant scatter. 


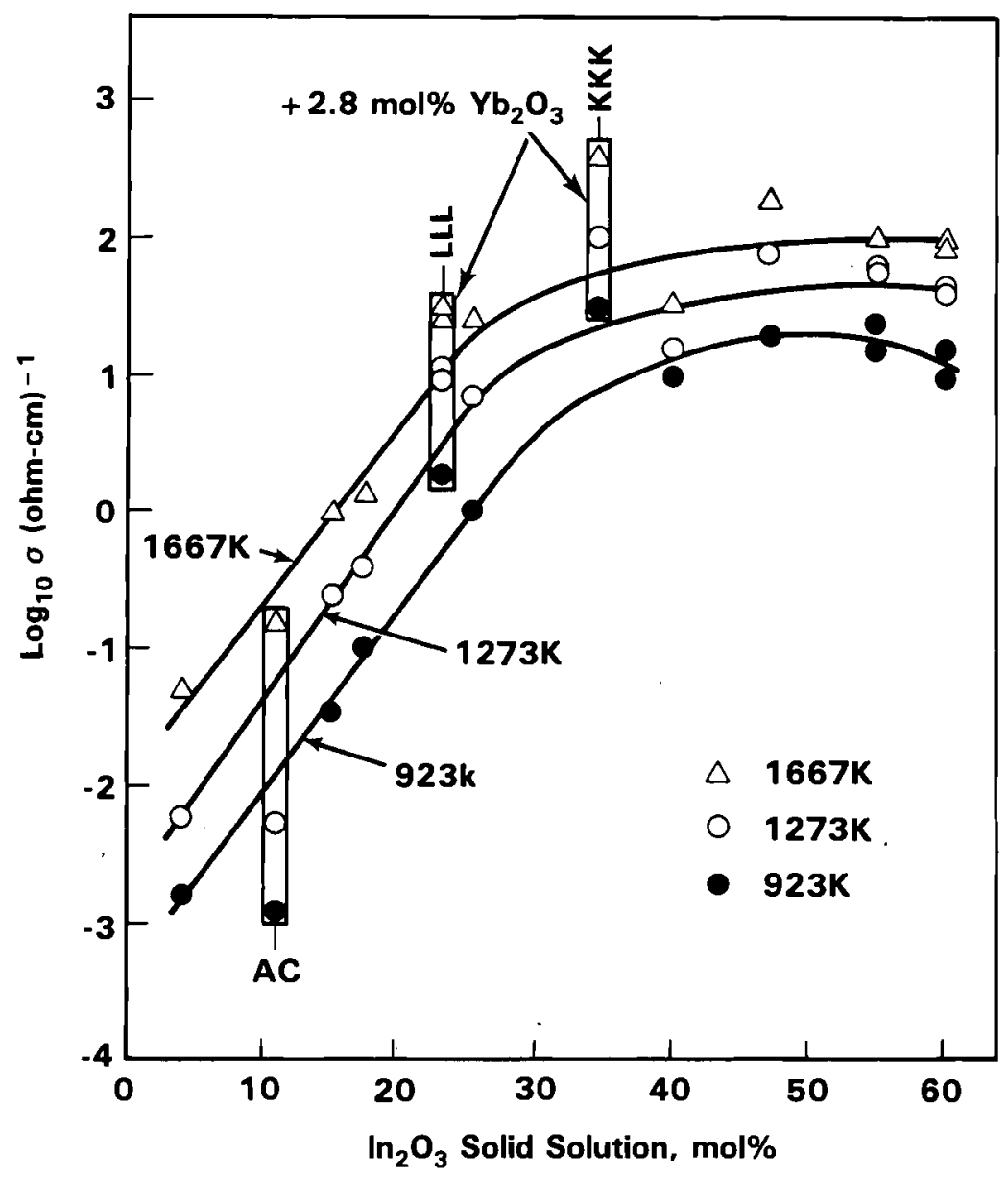

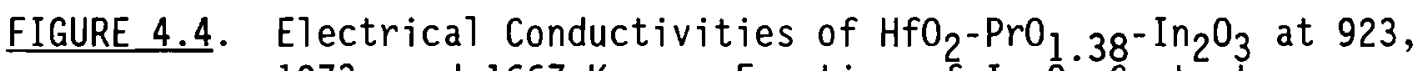
1273 , and $1667 \mathrm{~K}$ as a Function of $\mathrm{In}_{2} \mathrm{O}_{3}$ Content

However, there is a general decrease in both the high- and low-temperature activation energies with increases in both the $\operatorname{In}_{2} \mathrm{O}_{3}$ and the $\operatorname{In}_{2} \mathrm{O}_{3}$ (ss) concentrations. These data support the conclusion that the major conducting

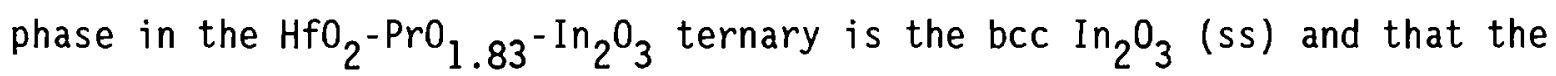
maximum conductivity value would be near $100 \mathrm{~mol} \% \mathrm{In}_{2} \mathrm{O}_{3}$, measured to be near $100(\mathrm{ohm}-\mathrm{cm})^{-1}$. The electrical conductivity of the $\mathrm{In}_{2} \mathrm{O}_{3}$ is expected to increase as the $\mathrm{HfO}_{2}$ and $\mathrm{PrO}_{1.83}$ are added as a solid solution, reaching a maximum at the maximum solubility as reported for other solid solutions of $\mathrm{In}_{2} \mathrm{O}_{3}$ (Bates et al. 1986). 


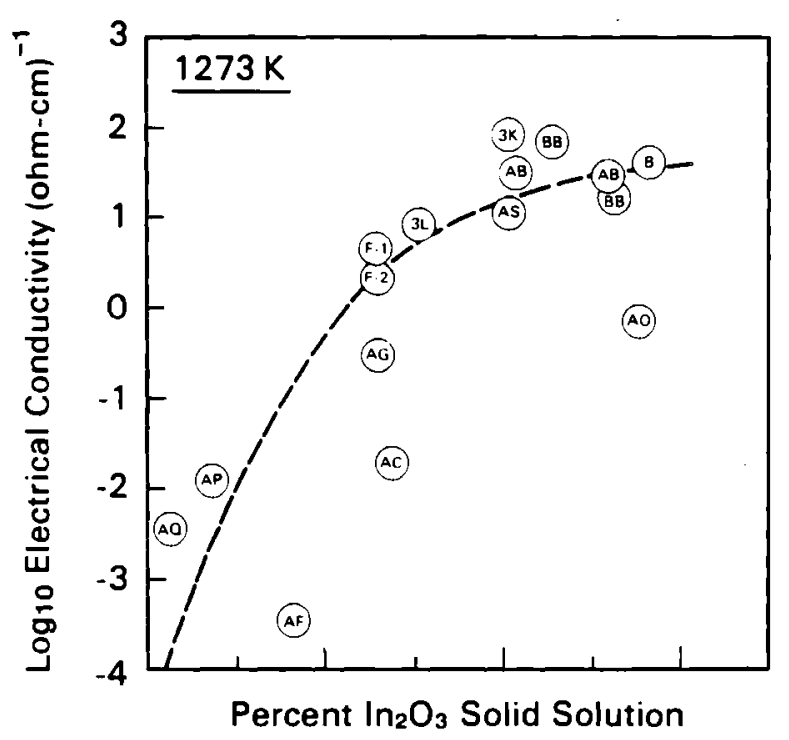

(a)

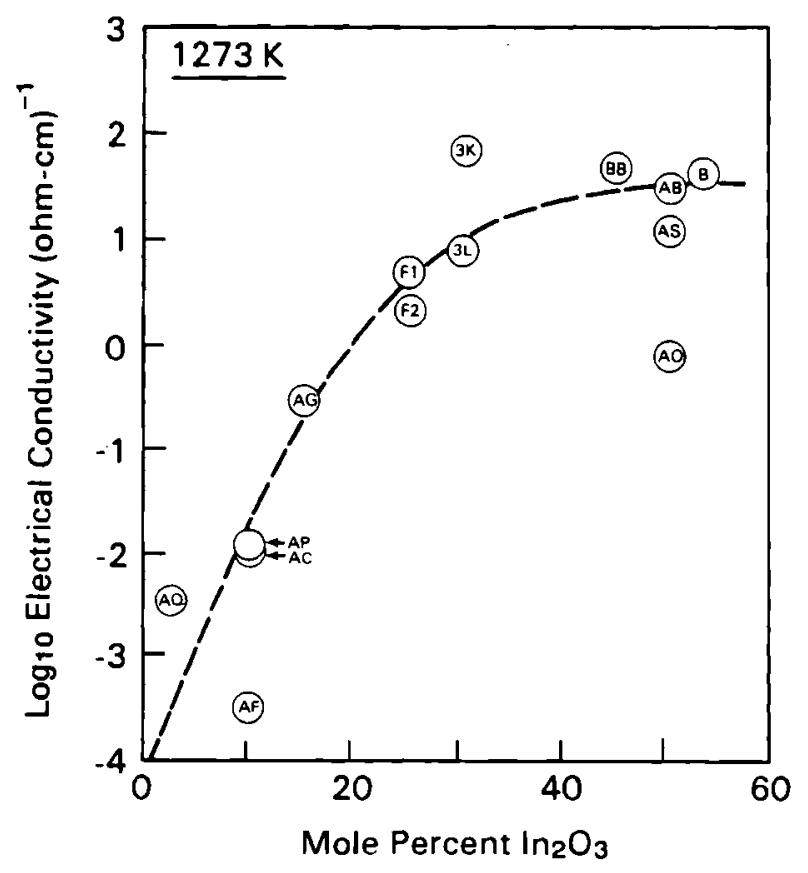

(b)

FIGURE 4.5. Electrical Conductivity at $1273 \mathrm{~K}$ of $\mathrm{HfO}_{2}-\mathrm{PrO}_{1.83}-\mathrm{In}_{2} \mathrm{O}_{3}$ Containing Small Amounts of $\mathrm{Yb}_{2} \mathrm{O}_{3}$ as a Function of (a) $\mathrm{In}_{2} \mathrm{O}_{3}$ Content and (b) $\mathrm{In}_{2} \mathrm{O}_{3}$ Solid Solution 
Many of the compositions summarized in Figures 4.3 through 4.5 and Tables 4.2 and 4.3 contain small concentrations of up to $6 \mathrm{~mol} \%$ of $\mathrm{Yb}_{2} \mathrm{O}_{3}$, in addition to $\mathrm{HfO}_{2}-\mathrm{PrO}_{1.83}-\mathrm{In}_{2} \mathrm{O}_{3}$. The conductivities, especially for $\mathrm{LLL}$ and KKK shown in Figure 4.3 , suggest that those samples containing $\mathrm{Yb}_{2} \mathrm{O}_{3}$ exhibit higher electrical conductivities than those without $\mathrm{Yb}_{2} \mathrm{O}_{3}$ but with similar amounts of $\mathrm{In}_{2} \mathrm{O}_{3}$. These compositions, as determined by XRD and SEM-EDX, are either two- or three-phase with one phase being bcc $\operatorname{In}_{2} \mathrm{O}_{3}$ (ss). In addition, the $\mathrm{Hf}_{2} \mathrm{In}_{2} \mathrm{O}_{7}$ phase contains some $\mathrm{PrO}_{1.83}$. These samples also show less hysteresis on heating and cooling than those without $\mathrm{Yb}_{2} \mathrm{O}_{3}$. The $\mathrm{x}$-ray diffraction data indicate that $\mathrm{Yb}_{2} \mathrm{O}_{3}$ tends to stabilize the $\mathrm{Hf}_{2} \mathrm{In}_{2} \mathrm{O}_{7}$ rhombohedral phase. These results suggest that other rare-earth oxides besides $\mathrm{Pr}_{1.83}$ may 1) form new conducting phases, 2) increase the $\mathrm{In}_{2} \mathrm{O}_{3}$ (ss), and/or 3) stabilize high-temperature phases and structures which revert on cooling either from the $\mathrm{In}_{2} \mathrm{O}_{3}$ (ss) or from another electrically conducting phase to the lower conducting pyrochlore phase.

In addition, the data also show the conductivity of a two-phase sample (AO) to be lower than that for the other oxides with observed high $B$ phase and containing $\mathrm{Yb}_{2} \mathrm{O}_{3}$. This composition is in a three-phase $\mathrm{Hf}_{2} \mathrm{Pr}_{2} \mathrm{O}_{7}$ $\mathrm{Hf}_{2} \mathrm{In}_{2} \mathrm{O}_{7}$ and $\mathrm{In}_{2} \mathrm{O}_{3}$ (ss) phase field. The lower conductivity is not consistent with the electrical conductivities of the other $\mathrm{HfO}_{2}-\mathrm{PrO}_{1.83}-\mathrm{In}_{2} \mathrm{O}_{3}$ compositions. Although not as pronounced, sample $A C$ and $A G$ also exhibit lower electrical conduction than the other compositions with equal $\operatorname{In}_{2} \mathrm{O}_{3}$ and $\mathrm{In}_{2} \mathrm{O}_{3}$ solid solutions. These three samples contain lower amounts of $\mathrm{PrO}_{1.83}$. This suggests that $\mathrm{Pr}_{1.83}$ may be requisite for higher electrical conductivities in addition to the $\mathrm{In}_{2} \mathrm{O}_{3}$ bcc phase.

It has been observed in this study that samples with composition in or near the two-phase $\mathrm{Hf}_{2} \mathrm{In}_{2} \mathrm{O}_{7}$ region may exhibit a hysteresis on heating and cooling during the electrical conductivity measurements. (See B-1 and MMM in Table 4.3). Although the oxides were sintered at $1823 \mathrm{~K}$ in air and measurements were made in air, some conductivity changes did occur on thermal cycling during the conductivity measurements. The magnitude of these changes varies between samples. 
Generally, the conductivity on cooling was higher than that on heating. For some samples, the two straight lines in the $\log \sigma$ versus $\mathrm{K}^{-1}$ were eliminated and the cooling curve was linear over the entire temperature range. The cause of these changes was not determined. However, the addition of $\mathrm{Yb}_{2} \mathrm{O}_{3}$ appeared to reduce this hysteresis and may be attributed to the possible stabilization of the $\mathrm{Hf}_{2} \mathrm{In}_{2} \mathrm{O}_{7}$ rhombohedral phase at high temperatures. This could reduce phase changes occurring during the measurement that alter conductivity values. It is possible that some vapor loss of the more volatile $\mathrm{In}_{2} \mathrm{O}_{3}$ may have resulted in a composition change. However, XRD and SEMEDX did not detect any change, especially near the sample surface.

\subsection{3 $\mathrm{HfO}_{2}-\mathrm{PrO}_{1.83}-\mathrm{In}_{2} \mathrm{O}_{3}$ Containing $\mathrm{Yb}_{2} \mathrm{O}_{3}$}

To determine the effects of small additions of $\mathrm{In}_{2} \mathrm{O}_{3}$ to the $\mathrm{HfO}_{2}$ $\mathrm{PrO}_{1.83}-\mathrm{In}_{2} \mathrm{O}_{3}$ system on the electrical conductivity and phase structure, the electrical conductivity was measured on a nominal $0.63 \mathrm{HfO}_{2} \cdot 0.27 \mathrm{PrO}_{1.83}{ }^{\circ}$ 0.10 yb01.5 base composition containing varied amounts of $\mathrm{In}_{2} \mathrm{O}_{3}$ as shown in Table 4.3. These structures contain both the rhombohedral and pyrochlore phases in addition to the bcc $\operatorname{In}_{2} \mathrm{O}_{3}$ (ss). The electrical conductivities of the compositions listed in Table 4.4 are shown in Figure 4.4. The electrical conductivities are shown in Table 4.3. The results suggest a sharp increase in electrical conductivity near $25 \mathrm{~mol}_{2} \mathrm{In}_{2} \mathrm{O}_{3}$, with a smaller increase above $30 \mathrm{~mol} \%$.

To determine the effect of $\mathrm{In}_{2} \mathrm{O}_{3}$ and the bcc $\mathrm{In}_{2} \mathrm{O}_{3}$ (ss) on the pyrochlore structure containing $\mathrm{Yb}_{2} \mathrm{O}_{3}$ but without the fluorite or rhombohedral phase, a series of compositions containing equal amounts of $\mathrm{HfO}_{2}$ and $\mathrm{PrO}_{1.83}$, $6 \mathrm{~mol} \% \mathrm{Yb}_{2} \mathrm{O}_{3}$ with varying amounts of $\mathrm{In}_{2} \mathrm{O}_{3}$ were studied in air to $1820 \mathrm{~K}$ (Table 4.4). The five compositions were $(0.94 \times)\left[0.5 \mathrm{HfO}_{2} \cdot 0.5 \mathrm{PrO}_{1.83}\right] \cdot \times \mathrm{In}_{2} \mathrm{O}_{3}$. $0.06 \mathrm{Yb}_{2} \mathrm{O}_{3}$ with $x$ between 20 and $40 \mathrm{~mol} \%$. The weight ratio of the bcc $\mathrm{In}_{2} \mathrm{O}_{3}$ (ss) and pyrochlore $\mathrm{HfO}_{2}-\mathrm{PrO}_{1.83}-\mathrm{In}_{2} \mathrm{O}_{3}-\mathrm{Yb}_{2} \mathrm{O}_{3}$ phases was determined by XRD.

The electrical conductivities are illustrated in Figure 4.6 and tabulated in Table 4.4 with a minimum conductivity between 20 and $25 \mathrm{~mol} \% \mathrm{In}_{2} \mathrm{O}_{3}$ and a sharp increase above $30 \mathrm{~mol} \% \mathrm{In}_{2} \mathrm{O}_{3}$. 
TABLE 4.4. Composition and Structure of $(0.94-x)\left[0.5 \mathrm{HfO}_{2} \cdot 0.5 \mathrm{PrO}_{1.83}\right]$
\[ \left(\mathrm{In}_{2} \mathrm{O}_{3}\right) \cdot 0.06 \mathrm{Yb}_{2} \mathrm{O}_{3} \]

\begin{tabular}{|c|c|c|c|c|c|c|}
\hline \multirow[b]{2}{*}{ Sample } & \multicolumn{4}{|c|}{ Composition, mol\% } & \multicolumn{2}{|c|}{ Phases, mo $\% \%^{(a, b)}$} \\
\hline & $\mathrm{HfO}_{2}$ & $\operatorname{PrO}_{1.83}$ & $\mathrm{In}_{2} \mathrm{O}_{3}$ & $\mathrm{Yb}_{2} \mathrm{O}_{3}$ & Pyrochlore & bcc \\
\hline FC- 157 & 27 & 27 & 40 & 6 & $48(50)$ & $42(50)$ \\
\hline FC- 153 & 29.5 & 29.5 & 35 & 6 & $54(55)$ & $36(45)$ \\
\hline FC- 154 & 32 & 32 & 30 & 6 & $70(65)$ & $30(35)$ \\
\hline FC- 155 & 34.5 & 34.5 & 25 & 6 & $75(60)$ & $25(40)$ \\
\hline$F C-156$ & 37 & 37 & 20 & 6 & $80(67)$ & $20(33)$ \\
\hline
\end{tabular}

(a) Determined by EDX.

(b) Determined by XRD.

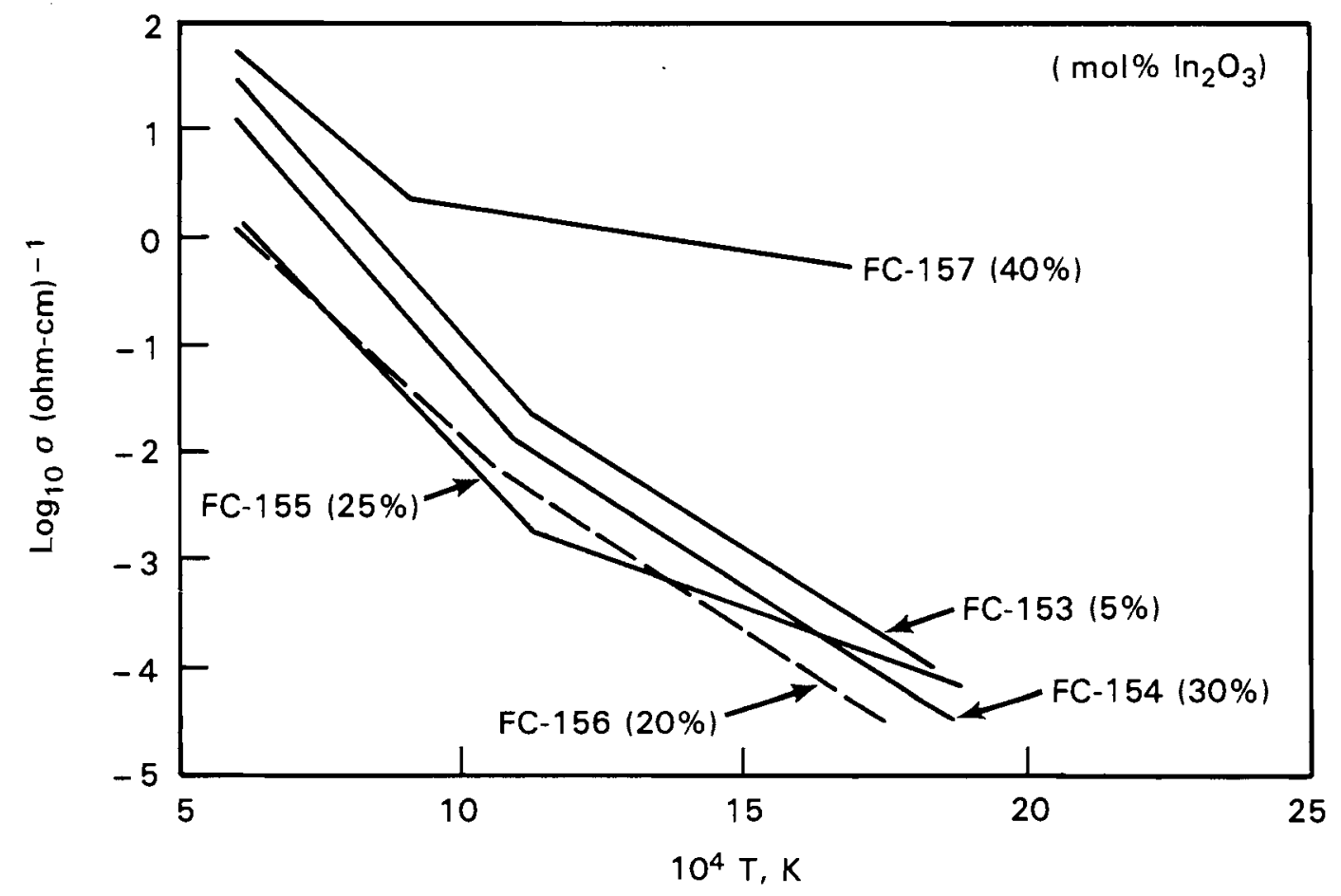

FIGURE 4.6. Electrical Conductivity of $(0.94-\mathrm{x}) \cdot\left[0.5 \mathrm{HfO}_{2} 0.5 \mathrm{PrO}_{1.83}\right]$
$\cdot x\left(\operatorname{In}_{2} \mathrm{O}_{3}\right) \cdot 0.06 \mathrm{Yb}_{2} \mathrm{O}_{3}$ in Air

\subsubsection{Heat Treatment}

The electrical conductivities were determined from 500 to $1600 \mathrm{~K}$ in air and after heat treatment in air at $1820 \mathrm{~K}$ for 48 hours. The electrical 

TABLE 4.5. Electrical Conductivity of $(0.94-x)\left[0.5 \mathrm{HfO}_{2} \cdot 0.5 \mathrm{PrO}_{1.83}\right] \cdot$
$\times\left(\operatorname{In}_{2} \mathrm{O}_{3}\right) \cdot 0.06 \mathrm{Yb}_{2} \mathrm{O}_{3}$

Temperature Activation

\begin{tabular}{|c|c|c|c|c|c|}
\hline Sample & $\frac{\log \sigma}{A}$ & $\frac{A-B / K}{B(103)}$ & $\begin{array}{c}\text { Range, } \\
\mathrm{K}\end{array}$ & $\begin{array}{c}\text { Energy, } \\
\mathrm{eV}\end{array}$ & $\begin{array}{l}\text { Coefficient of } \\
\text { Determination }\end{array}$ \\
\hline $\mathrm{FC}-157$ & $\begin{array}{l}4.268 \\
1.094\end{array}$ & $\begin{array}{l}4.253 \\
0.777\end{array}$ & $\begin{array}{r}1109-1576 \\
578-1109\end{array}$ & $\begin{array}{l}0.84 \\
0.15\end{array}$ & $\begin{array}{l}0.992 \\
0.922\end{array}$ \\
\hline $\mathrm{FC}-157 \mathrm{HT}(\mathrm{a})$ & $\begin{array}{l}4.841 \\
1.551\end{array}$ & $\begin{array}{l}5.376 \\
2.482\end{array}$ & $\begin{array}{r}879-1579 \\
503-879\end{array}$ & $\begin{array}{l}1.07 \\
0.49\end{array}$ & $\begin{array}{l}0.994 \\
0.984\end{array}$ \\
\hline FC-153 & $\begin{array}{l}5.020 \\
2.035\end{array}$ & $\begin{array}{l}5.892 \\
3.259\end{array}$ & $\begin{array}{r}890-1588 \\
503-890\end{array}$ & $\begin{array}{l}1.17 \\
0.65\end{array}$ & $\begin{array}{l}0.998 \\
0.992\end{array}$ \\
\hline $\mathrm{FC}-153 \mathrm{HT}$ & $\begin{array}{l}4.968 \\
2.335\end{array}$ & $\begin{array}{l}5.960 \\
3.577\end{array}$ & $\begin{array}{r}888-1580 \\
518-888\end{array}$ & $\begin{array}{l}1.18 \\
0.71\end{array}$ & $\begin{array}{l}0.996 \\
0.997\end{array}$ \\
\hline FC -154 & $\begin{array}{l}4.657 \\
1.771\end{array}$ & $\begin{array}{l}5.910 \\
3.377\end{array}$ & $\begin{array}{r}885-1597 \\
510-885\end{array}$ & $\begin{array}{l}1.17 \\
0.66\end{array}$ & $\begin{array}{l}0.004 \\
0.995\end{array}$ \\
\hline $\mathrm{FC}-154 \mathrm{HT}$ & 4.944 & 6.404 & $104-1575$ & 1.27 & 0.995 \\
\hline$F C-155$ & $\begin{array}{r}3.524 \\
-0.656\end{array}$ & $\begin{array}{l}5.517 \\
1.841\end{array}$ & $\begin{array}{r}878-1599 \\
500-878\end{array}$ & $\begin{array}{l}1.10 \\
0.37\end{array}$ & $\begin{array}{l}0.984 \\
0.874\end{array}$ \\
\hline FC -156 & $\begin{array}{l}2.969 \\
1.367\end{array}$ & $\begin{array}{l}4.163 \\
3.313\end{array}$ & $\begin{array}{r}1101-1564 \\
552-1101\end{array}$ & $\begin{array}{l}0.95 \\
0.66\end{array}$ & $\begin{array}{l}0.990 \\
0.996\end{array}$ \\
\hline $\mathrm{FC}-156 \mathrm{HT}$ & $\begin{array}{r}2.972 \\
-0.139\end{array}$ & $\begin{array}{l}4.798 \\
2.084\end{array}$ & $\begin{array}{rr}868-1578 \\
534-868\end{array}$ & $\begin{array}{l}0.95 \\
0.41\end{array}$ & $\begin{array}{l}0.986 \\
0.962\end{array}$ \\
\hline
\end{tabular}

(a) $H T=$ Heat treated in air at $1820 \mathrm{~K}$ for $45 \mathrm{~h}$.

conductivities, as shown in Table 4.5 and Figure 4.7 , were changed by heat treatment. A large decrease in conductivity was noted for the composition with the highest $\mathrm{In}_{2} \mathrm{O}_{3}$ content, $\mathrm{FC}-157(40 \mathrm{~mol} \%)$. In contrast, the composition with the highest indium content--FC-156 with 20 mol\%--exhibited little change at high temperatures. Below $900 \mathrm{~K}$, the conductivity of the heattreated sample was higher than the as-fabricated sample. These changes may relate to the loss of $\mathrm{In}_{2} \mathrm{O}_{3}$ or $\mathrm{Pr}_{1.83}$ during heat treatment. All heattreated samples experienced some small weight loss, with the greatest loss 


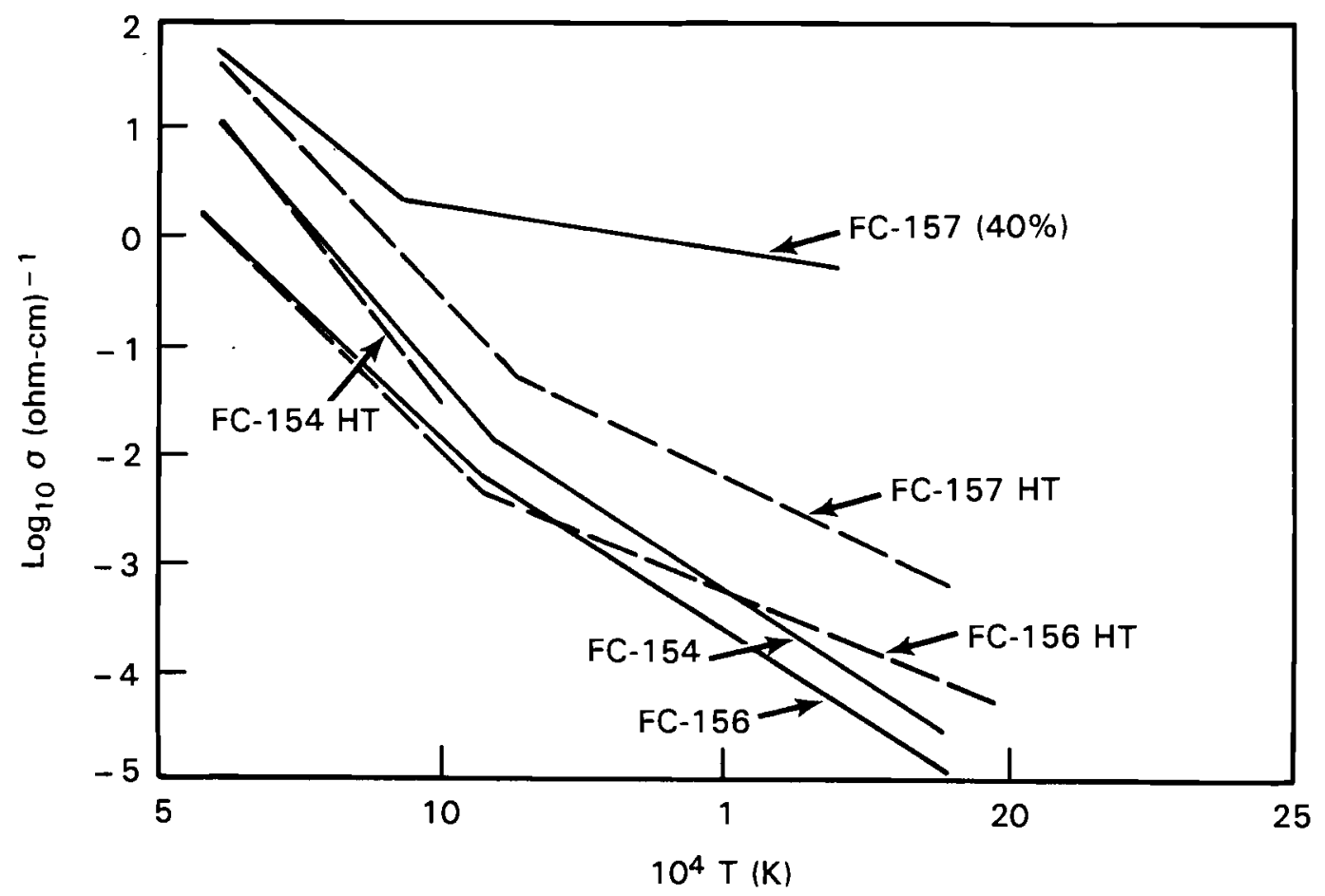

FIGURE 4.7. Electrical Conductivity of $(0.94-\mathrm{x})\left[0.5 \mathrm{HfO}_{2}\right.$ $\left.0.5 \operatorname{PrO}_{1.83}\right] \cdot x\left(\operatorname{In}_{2} \mathrm{O}_{3}\right) \cdot 0.06 \mathrm{Yb}_{2} \mathrm{O}_{3}$ Before and After Heat Treatment in Air at $1820 \mathrm{~K}$ for 48 Hours (HT)

observed for the higher- $\operatorname{In}_{2} \mathrm{O}_{3}$ oxides. However, XRD before and after heat treatment exhibited the same bcc and pyrochlore structures with only a slight increase in the bcc $\operatorname{In}_{2} \mathrm{O}_{3}$ (ss) phase.

The electrical conductivities, similar to other samples, increased with both increasing $\mathrm{In}_{2} \mathrm{O}_{3}$ content and bcc phase content. At $1270 \mathrm{~K}$, a plot of $\log \sigma$ versus mol\% in the $\operatorname{In}_{2} \mathrm{O}_{3}$ was nearly linear as shown in Figure 4.8. The $25 \mathrm{~mol} \% \mathrm{In}_{2} \mathrm{O}_{3}$ composition deviated from this general pattern, exhibiting a higher bcc phase concentration, a lower electrical conductivity, and an activation energy different than expected from other trends in the data. Although there is more scatter in the data, a decrease in the electrical conductivities was also observed at $1000 \mathrm{~K}$ but with a large increase above $35 \mathrm{mo} \% \mathrm{In}_{2} \mathrm{O}_{3}$ solid solution or $35 \mathrm{~mol} \% \mathrm{In}_{2} \mathrm{O}_{3}$. This high- $\mathrm{In}_{2} \mathrm{O}_{3}$-containing sample also exhibited the largest decrease in electrical conductivity on cooling. The reasons for these deviations are not known. 


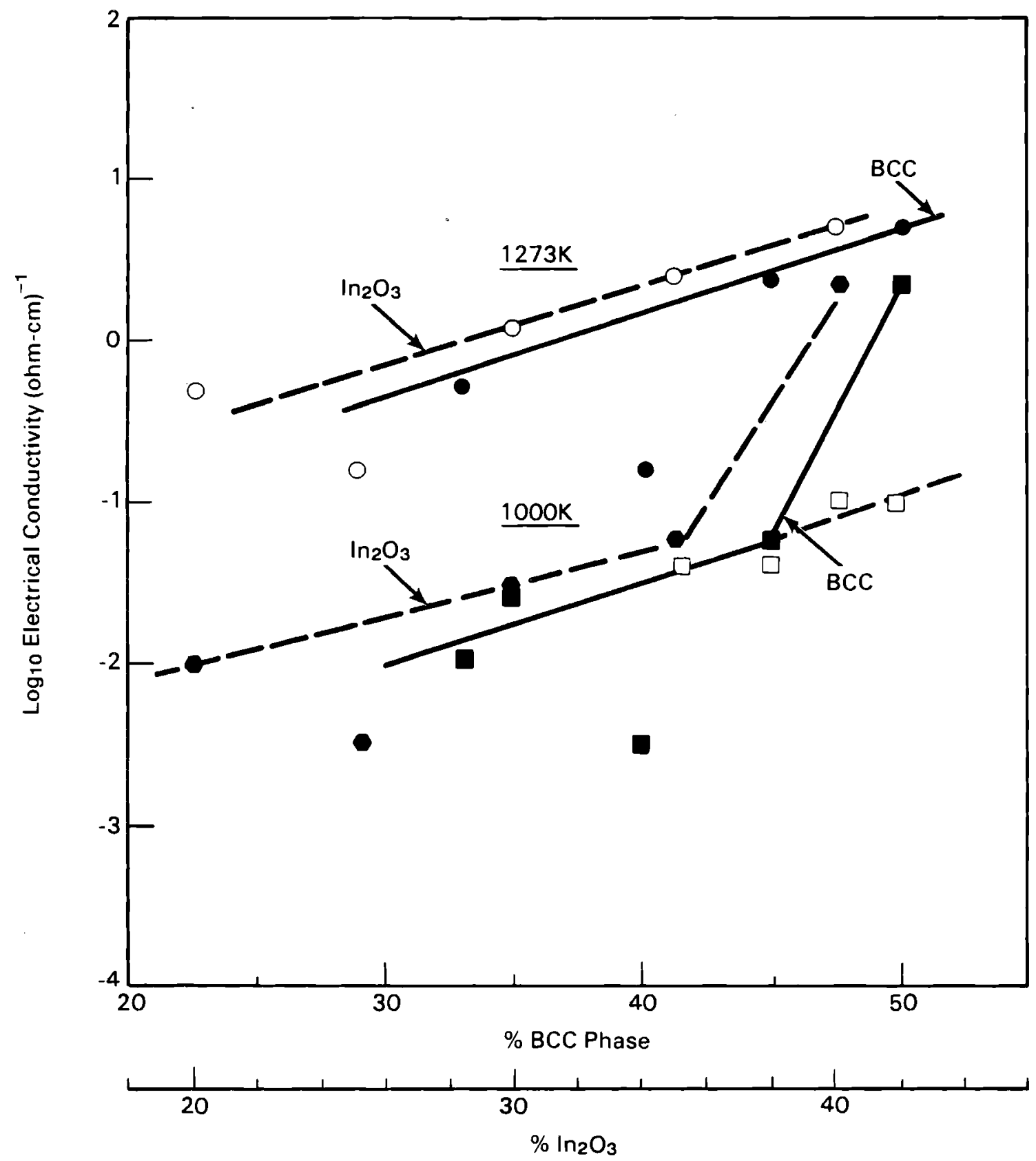

FIGURE 4.8. Electrical Conductivity at 1000 and $1273 \mathrm{~K}$ as a Function of $\mathrm{In}_{2} \mathrm{O}_{3}$ and $\mathrm{In}_{2} \mathrm{O}_{3}$ Solid Solution Content for $\mathrm{HfO}_{2}-\mathrm{PrO}_{1.83}-\mathrm{In}_{2} \mathrm{O}_{3}$ with $6 \mathrm{~mol} \% \mathrm{Yb}_{2} \mathrm{O}_{3}$ 
The electrical conductivity for these compositions is lower than conductivities for similar compositions measured earlier. The reason for these differences is not known; however, some fabrication or structural variations may be a factor. Furthermore, the small addition of $\mathrm{Yb}_{2} \mathrm{O}_{3}$ to the two-phase $\mathrm{HfO}_{2}-\mathrm{PrO}_{2}-\mathrm{In}_{2} \mathrm{O}_{3}$ phase region does not appear to stabilize the pyrochlore or a rhombohedral structure or reduce the bcc $\operatorname{In}_{2} \mathrm{O}_{3}$ solid solution.

\subsubsection{Oxygen Pressure}

Electrical conductivities of selected samples were measured at Marquette University, Milwaukee, Wiscons in for PNL, in conjunction with electrochemical transport measurements. Measurements were made using a four-contact ac and dc method as a function of oxygen pressure. The data for two samples, $0.38 \mathrm{HfO}_{2} \cdot 0.38 \mathrm{PrO}_{2} \cdot 0.206 \mathrm{In}_{2} \mathrm{O}_{3} \cdot 0.02 \mathrm{Yb}_{2} \mathrm{O}_{3}(\mathrm{FC}-130-1)$ and $0.39 \mathrm{HfO}_{2} \cdot 0.391 \mathrm{PrO}_{2} \cdot$ $0.208 \mathrm{In}_{2} \mathrm{O}_{3} \cdot 0.01 \mathrm{Y}_{2} \mathrm{O}_{3}(\mathrm{FC}-133-1,2)$, were compared with values obtained at PNL on sibling samples in air for comparison with a similar four-contact dc method.

For the $\mathrm{Y}_{2} \mathrm{O}_{3}$-containing oxide, $\mathrm{FC}-133-1$ (Figure 4.9) the initial measurements were made in $1 \mathrm{~atm}$ of oxygen. The conductivity was higher on heating to $1280 \mathrm{~K}$ than on cooling. Subsequent thermal cycling showed no hysteresis. The electrical conductivity for a similar composition measured in air at PNL using a four-contact method was lower than the Marquette results and the hysteresis was reduced. As shown in Figure 4.10, the electrical conductivity between 1090 and $1280 \mathrm{~K}$ increased with decreasing oxygen pressure. The experimental activation energy varied between 0.5 and $0.6 \mathrm{eV}$ in oxygen partial pressure from 1 to $10-3.48 \mathrm{~atm}$. The activation energies were slightly higher for the higher oxygen pressures. At very low oxygen partial pressures, that is at less than 10-16 atm, the electrical conductivities were relatively constant with temperature.

The increasing conductivity with decreasing oxygen partial pressure is characteristic of $n$-type behavior and is consistent with the transference numbers that are predominantly electronic, as described later.

In contrast, the electrical conductivity of the $0.387 \mathrm{HfO}_{2} \cdot 0.387 \mathrm{PrO}_{2}$. $0.206 \mathrm{In}_{2} \mathrm{O}_{3} \cdot 0.02 \mathrm{Yb}_{2} \mathrm{O}_{3}$ showed no hysteresis after heating to $1290 \mathrm{~K}$ 


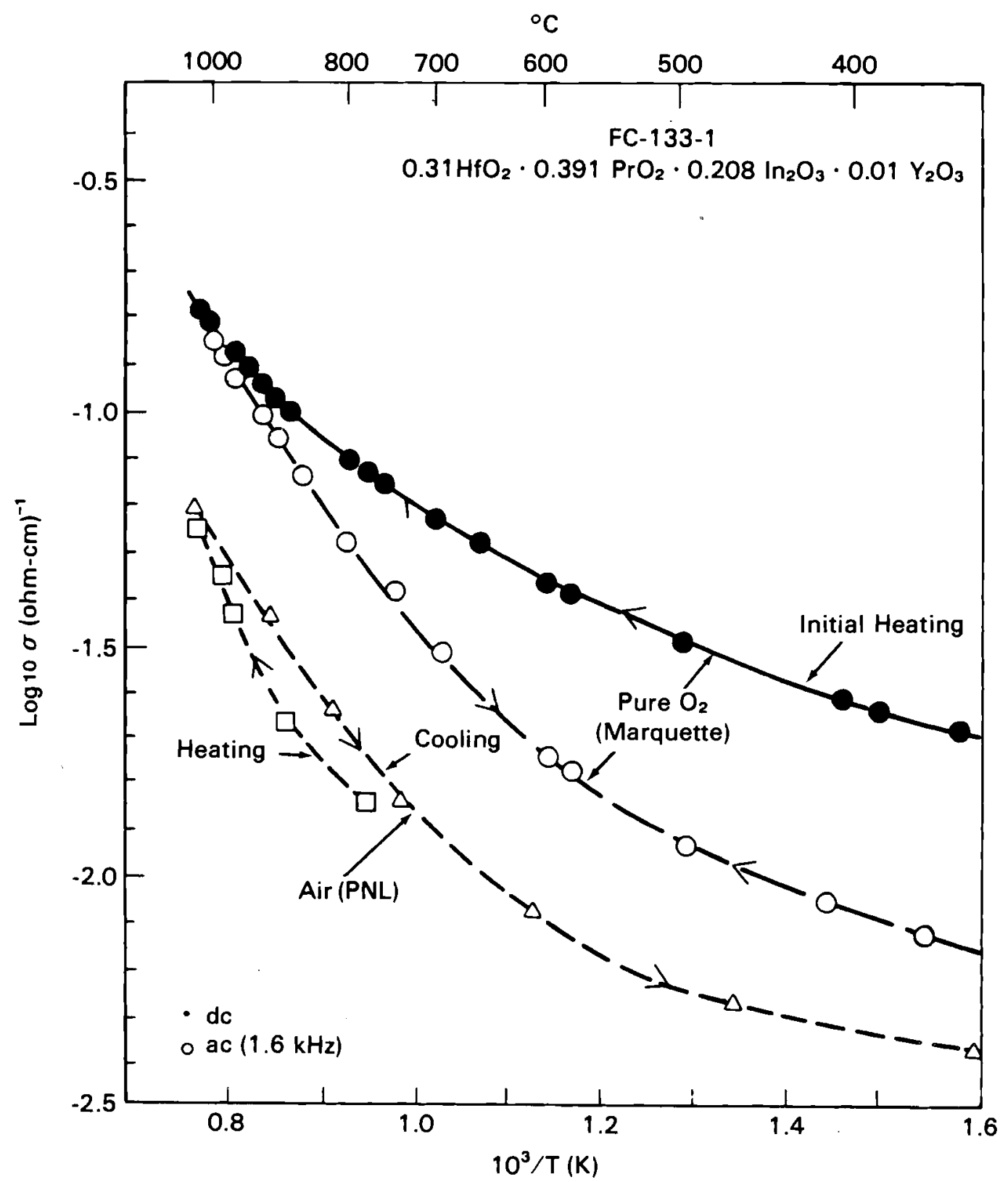

FIGURE 4.9. Electrical Conductivity of $0.39 \mathrm{HfO}_{2} \cdot 0.3 \mathrm{PrO}_{1.83^{\circ}}$ $0.208 \mathrm{In}_{2} \mathrm{O}_{3} \cdot 0.01 \mathrm{Yb}_{2} \mathrm{O}_{3}$ in Oxygen and in Air 


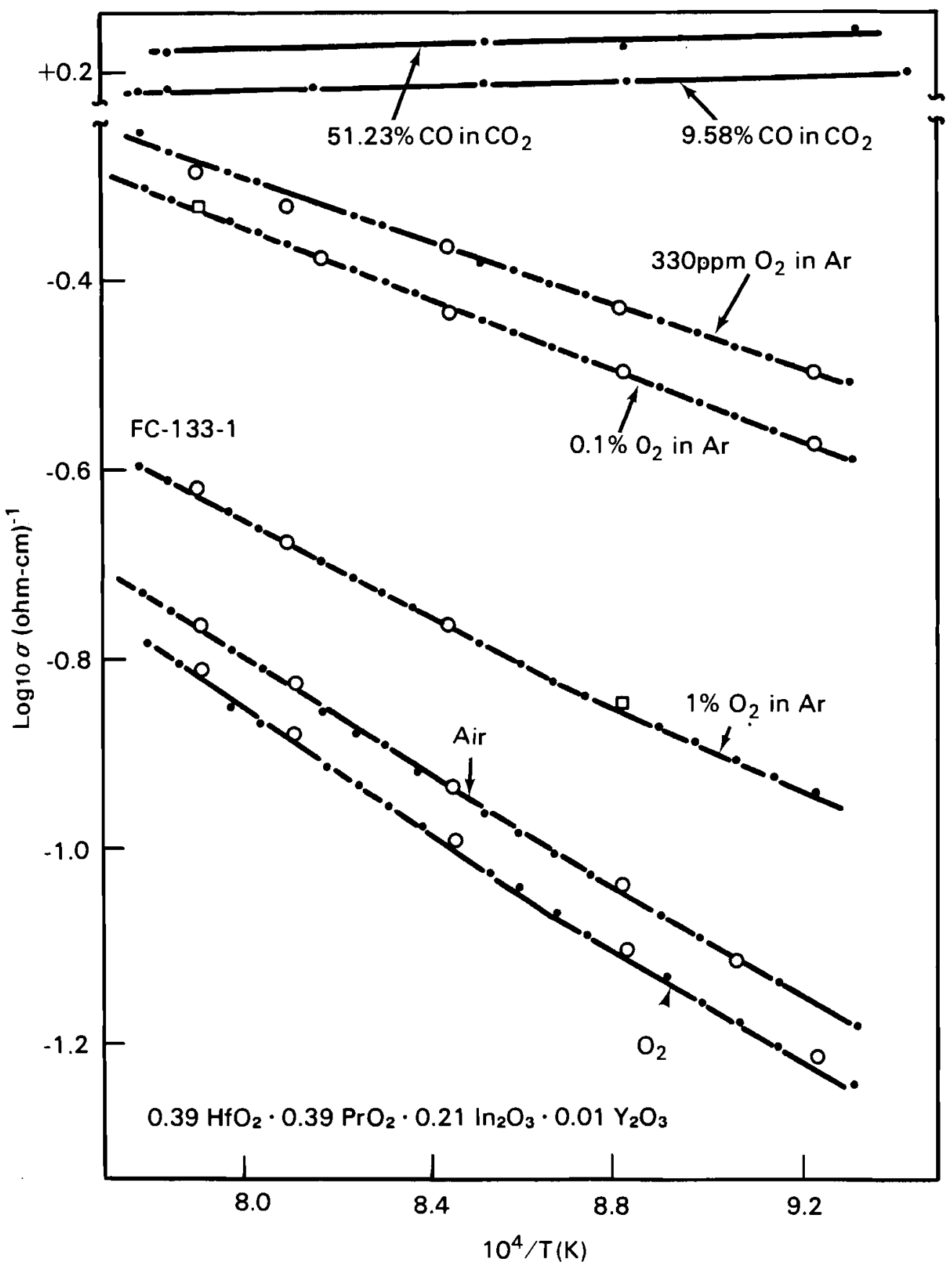

FIGURE 4.10. Electrical Conductivity of $0.39 \mathrm{HfO}_{2} \cdot 0.39 \mathrm{PrO}_{1} .83 \cdot 0.21 \mathrm{Yb}_{2} \mathrm{O}_{3}$ as a Function of Oxygen Pressure 


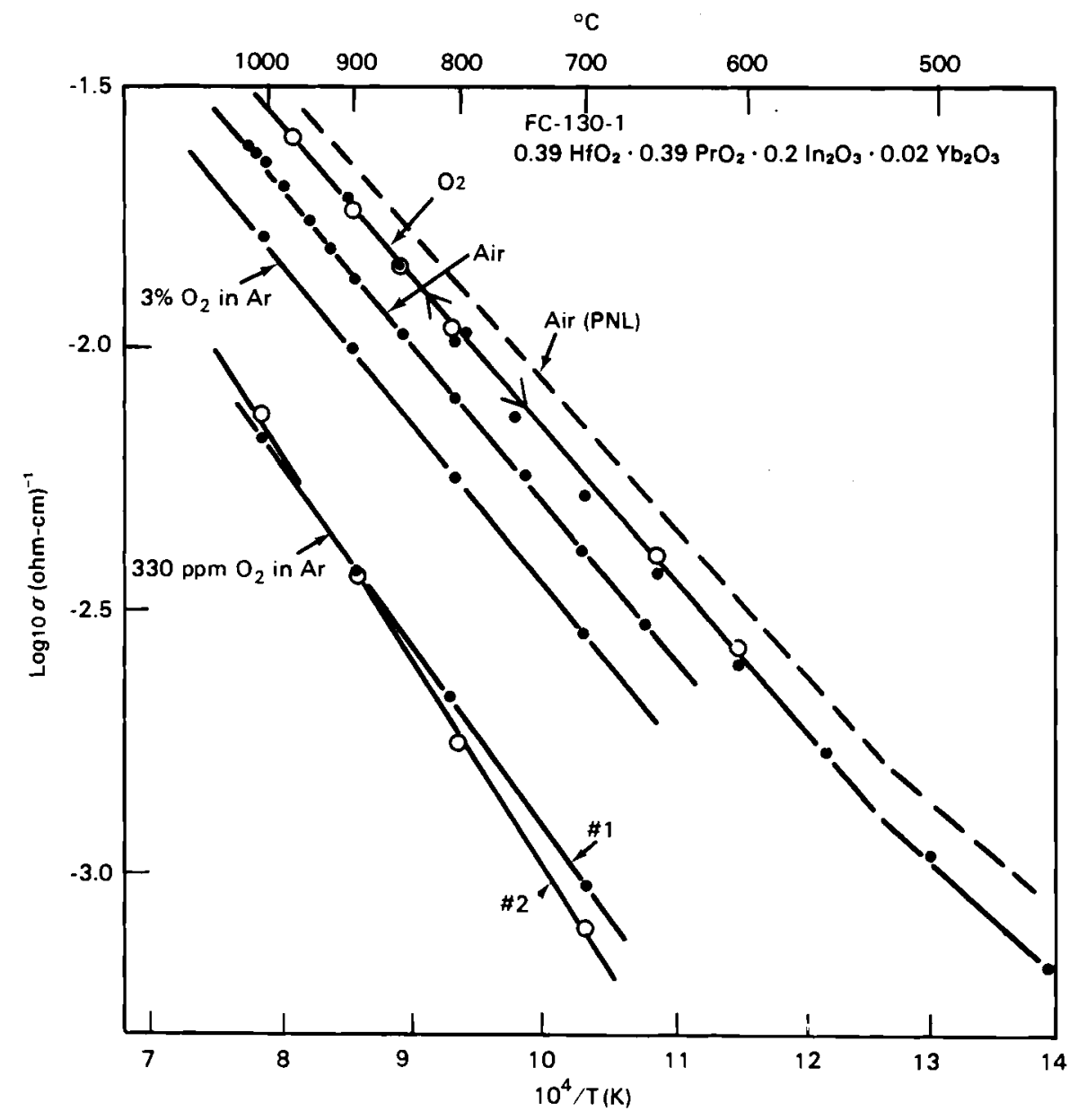

FIGURE 4.11. Electrical Conductivity of $0.31 \mathrm{HfO}_{2} \cdot 0.39 \mathrm{PrO}_{1} \cdot 83 \cdot 0.2 \mathrm{In}_{2} \mathrm{O}_{3}$ $.0 .02 \mathrm{Yb}_{2} \mathrm{O}_{3}$ as a Function of Oxygen Pressure

(Figure 4.11). In addition, the electrical conductivity decreased with decreasing oxygen partial pressure, suggesting p-type electrical transport behavior. The activation energies between 920 and $1290 \mathrm{~K}$ varied between 0.6 and $0.7 \mathrm{eV}$ with slightly higher energies for the lower oxygen pressures. The transference numbers detailed later also showed very high electronic transference values. For this composition, the conductivities measurements made in air at PNL were less than an order of magnitude higher than those measured at Marquette. 


\subsection{SEEBECK COEFFICIENTS}

The Seebeck coefficients were determined by applying a temperature gradient along the length of rectangular bars similar to those used for electrical conductivity measurements and by measuring the potential (V) and temperature $(T)$ differences. Four Pt-Pt/10Rh thermocouples in contact with the sample bar were used to measure temperatures and potentials along the bar, providing a combination of six $V / T$ values. The absolute Seebeck coefficient was determined from the least-squares analysis of the six data points. The 3- $\sigma$ error in the A Seebeck coefficients was estimated to be $\pm 2.8 \%$.

Two compositions were selected for Seebeck coefficient determination: $0.30 \mathrm{In}_{2} \mathrm{O}_{3} \cdot 0.033 \mathrm{Yb}_{2} \mathrm{O}_{3} \cdot 0.20 \mathrm{PrO}_{1.83} \cdot 0.467 \mathrm{HfO}_{2}(\mathrm{LLL})$ and $0.433 \mathrm{In}_{2} \mathrm{O}_{3} \cdot 0.036 \mathrm{Y}_{2} \mathrm{O}_{3}$ $0.035 \mathrm{~Tb} 407 \cdot 0.496 \mathrm{HfO}_{2}$ (MMM). The thermoelectric powers are shown in Figure 4.12. The MMM composition exhibits higher electrical conductivities and

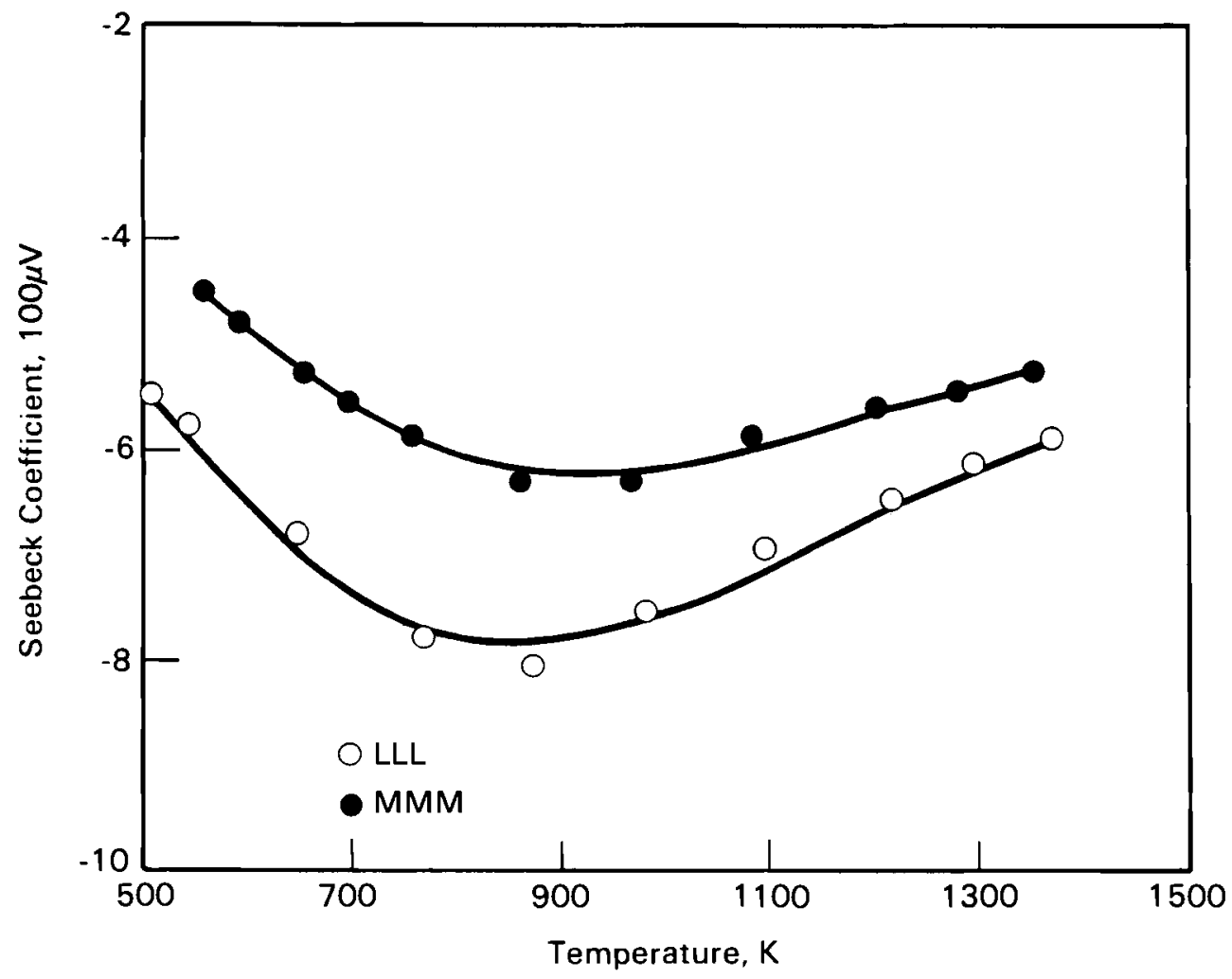

FIGURE 4.12. Seebeck Coefficient of $\mathrm{HfO}_{2}-\mathrm{PrO}_{1.83}-\mathrm{In}_{2} \mathrm{O}_{3}-\mathrm{Yb}_{2} \mathrm{O}_{3}$ (LLL and MMM) as a Function of Temperature 
lower Seebeck coefficients. However, both have moderately negative values near $100 \mu \mathrm{V} / \mathrm{K}$ and exhibit a maximum negative value near $900 \mathrm{~K}$. Additional qualitative studies of other compositions and structures indicate the following:

- FCC $\mathrm{In}_{2} \mathrm{O}_{3}$ stabilized $\mathrm{HfO}_{2}--$ large positive values consistent with oxygen ion vacancy conductivity

- $\mathrm{BCC} \mathrm{In}_{2} \mathrm{O}_{3}$ (ss)--low 25 to 150 negative values consistent with an electronic conducting, degenerate semi-conductor

- $\mathrm{Hf}_{2} \mathrm{Pr}_{2} \mathrm{O}_{7}--$ large positive values consistent with an insulator

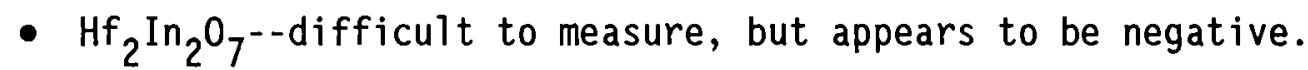

The two- and three-phase structures appear to be combinations of these phases, which give rise to maxima and minima in the Seebeck coefficient curves as a function of temperature and to changes in the sign of the Seebeck coefficient.

\subsection{TRANSFERENCE NUMBERS}

In characterizing high-temperature transport properties of electrically conducting oxides for SOFC, it is important to determine the electronic and ionic contributions to the total electrical conductivity and the conductivity dependence on oxygen pressure. For applications, as SOFC electrodes and current interconnectors, the oxides must conduct electronically. To understand the transport properties and the electrochemical interactions with the solid electrolyte, the actual amount of current transported by either ions or electrons needs to be known.

Two experimental techniques were used to determine transference numbers. The electrochemical oxygen-half cell is generally the simplest, and accurate measurements can be made relatively quickly when the transference number is between 0.05 and 0.95 . Details of the method have been described in many studies of transport properties.

A coulometric titration cell technique was used to measure the transference numbers with high sensitivity $\left[0.001<\bar{t}_{j} 0.999\left(\bar{t}_{j}\right.\right.$ and $\bar{t}_{e}$ are the 
average fractions transported by ionic and electronic carriers, respectively)]. The solid-state coulombic cell uses separate reference and working electrodes enclosed in an $\mathrm{Al}_{2} \mathrm{O}_{3}$ tube to measure oxygen permeability. Oxygen is pumped in and out of the interior of the cell by the application of a known electromotive force (emf) to the reference electrode, made of totally ionically conducting $\mathrm{Y}_{2} \mathrm{O}_{3}$ - or CaO-stabilized $\mathrm{ZrO}_{2}$.

The oxygen potentials across the working electrode are established at equilibrium and the change in emf is used to determine the transference number and mobility of the minority carrier.

Two $\mathrm{HfO}_{2}-\mathrm{RE}_{x} \mathrm{O}_{y}-\mathrm{In}_{2} \mathrm{O}_{3}$ compositions were studied using the coulombic titration cell technique. The two compositions evaluated were $0.39 \mathrm{HfO}_{2}$. $0.39 \mathrm{PrO}_{2} \cdot 0.01 \mathrm{Y}_{2} \mathrm{O}_{3} \cdot 0.21 \mathrm{In}_{2} \mathrm{O}_{3}(\mathrm{FC}-131-3)$ and $0.39 \mathrm{HFO}_{2} \cdot 0.39 \mathrm{PrO}_{2} \cdot 0.02 \mathrm{Yb}_{2} \mathrm{O}_{3} \cdot$ $0.21 \mathrm{In}_{2} \mathrm{O}_{3}(F C-130-6)$. For $\mathrm{FC}-131-3$, the electronic transference numbers, $\bar{t}_{e}$, are greater than 0.99 in the 1070 to $1290 \mathrm{~K}$ temperature range and for oxygen partial pressures between 10-3.48 and 1 atm (Table 4.6). Lower oxygen partial pressures of 10-12 to 10-18 atm showed an even higher electronic contribution to conductivity.

For FC-130-6, the ionic transference number is even smaller than for FC-133, that is, 0.0022 at $1220 \mathrm{~K}$ compared to 0.010 for FC-130-1. FC-133 are $n$-type and appear to be degenerate semiconductors while FC-136 are p-type. These data are consistent with the electrical conductivity and Seebeck coefficient data described previously. However, the reason for the difference due specifically to $\mathrm{Y}_{2} \mathrm{O}_{3}$ and $\mathrm{Yb}_{2} \mathrm{O}_{3}$ is not understood.

TABLE 4.6. Transference Numbers for FC-133-1

Temperature,

\begin{tabular}{|c|c|c|}
\hline K & $\bar{t}_{e}$ & $\bar{t}_{i}=1-\bar{t}_{e}$ \\
\hline 1220 & 0.990 & 0.010 \\
\hline 1170 & 0.993 & 0.007 \\
\hline 1120 & 0.994 & 0.006 \\
\hline 1070 & 0.995 & 0.005 \\
\hline
\end{tabular}




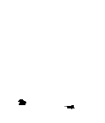




\subsection{CONCLUSIONS}

The following conclusions can be made concerning solid oxide fuel cells:

- An aqueous, coprecipitation process was developed for synthesizing homogeneous, crystalline powders for fabricating high-density oxides for phase equilibria and electrical transport studies.

- A ternary phase diagram at $1824 \mathrm{~K}$ was developed for the $\mathrm{HfO}_{2}-\mathrm{PrO}_{1.83}-\mathrm{In}_{2} \mathrm{O}_{3}$ in air. The development utilized a new, quantitative, micro-spot energy dispersive $x$-ray spectrographic system coupled with scanning electron microscopy, x-ray diffraction, and metallography. Two new phases were identified: an orthorhombic $\mathrm{PrInO}_{3}$ and a rhombohedral $\mathrm{Hf}_{2} \mathrm{In}_{2} \mathrm{O}_{7}$.

- $\mathrm{In}_{2} \mathrm{O}_{3}$ forms a bcc solid solution containing up to $10 \mathrm{~mol} \% \mathrm{HfO}_{2}+$ $\mathrm{PrO}_{1.83}$. The $\mathrm{HfO}_{2}$ is as stable as the $\mathrm{fcc}$, fluorite phase with from 10 to $24 \mathrm{~mol}_{\%} \mathrm{In}_{2} \mathrm{O}_{3}$.

- The high electronic conductivity in the $\mathrm{HfO}_{2}-\mathrm{PrO}_{1.83}-\mathrm{In}_{2} \mathrm{O}_{3}$ system appears related to the presence of the $\mathrm{In}_{2} \mathrm{O}_{3}$ solid solution. This phase appears to be an $n$-type, degenerate semiconductor.

- The $\mathrm{Hf}_{2} \mathrm{In}_{2} \mathrm{O}_{7}$ phase is an oxide semiconductor with conductivities at $1000 \mathrm{~K}^{2}$ near $5 \times 10^{-1}(\mathrm{ohm}-\mathrm{cm})^{-1}$. The $\mathrm{PrInO}_{3}$ phase is an electrical insulator.

- The two- or three-phase oxides containing more than $35 \mathrm{~mol} \% \mathrm{In}_{2} \mathrm{O}_{3}$ solid solution have electrical conductivities $\left[<10^{1}(\mathrm{ohm}-\mathrm{cm})^{-1}\right]$, suitable as electrodes for solid oxide fuel cells. These oxides are mixed ionic-electronic conductors with less than $0.2 \%$ ionic conduction. The structures of the oxides between 35 and $50 \mathrm{~mol} \%$ In203 solid solution have thermal and chemical properties compatible with the $\mathrm{Y}_{2} \mathrm{O}_{3}$-stabilized $\mathrm{ZrO}_{2}\left(\mathrm{HfO}_{2}\right)$ solid electrolyte. 


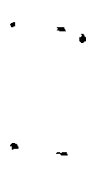

$-$ ( 


\subsection{ACKNOWLEDGMENTS}

The authors acknowledge the contributions of D. D. Marchant who participated in the initial research at PNL, and D. I. Boget, W. E. Gerry, and G. E. Davison, who conducted many of the experiments. The authors also acknowledge the support of the U.S. Department of Energy's Fossi1 Energy Materials Program, through 0ak Ridge National Laboratory. 
. 


\subsection{REFERENCES}

Aleshin E., and R. Roy. 1962. "Crystal Chemistry of Pyrochlore." J.Am. Ceram. Soc. 45:18-25.

Bates, J. L., and C.W. Griffin. 1986. "Oxide Electrodes for Solid Oxide Fuel Cells." 1986 Fuel Cell Seminar, Tucson, Arizona, October 26-29, Courtesy Associates, Washington, D.C. pp. 28-31.

Bates, J. L., and D. D. Marchant. 1978. "Thermal Properties of MHD Electrode Materials." Seventeenth Symposium of Engineering Aspects of Magnetohydro-dynamics, pp. D.6.1-7.

Bates, J. L., and D. D. Marchant. 1984. "Oxide Electrodes for HighTemperature Fuel Cells, " Fossil Energy Materials Program Quarterly Progress Report for the Period Ending March 31, 1984. ORNL/FMP-84/2, Oak Ridge National Laboratory, Oak Ridge, Tennessee.

Bates, J. L., and D. D. Marchant. 1986. Development of Materials for OpenCycle Magnetohydrodynamics (MHD): Ceramic Electrode, Final Report, PNL-5942. Pacific Northwest Laboratory, Richland, Washington.

Bates, J. L., C. W. Griffin, D. D. Marchant, and J. E. Garnier. 1986. "Electrical Conductivity, Seebeck Coefficient and Structure of $\mathrm{In}_{2} \mathrm{O}_{3}-\mathrm{SnO}_{2}$. Bul1. Am. Cer. Soc. 65(4):673-678.

Brauer, G. K. and B. Willaredt. 1980. "Oxidation of Praseodymia in Ternary Rare Earth 0xide Phases." The Rare Earths in Modern Science and Technology, Vol 2. eds. G. J. McCarthy, J. J. Rhyme and H. B. Silber. Plenum Press, New York, pp. 187-188.

Dollard, W. J., and J. T. Brown. 1986. "Overview of the Westinghouse Solid Oxide Fuel Cell Program." 1986 Fuel Cell Seminar, Tucson, Arizona, October 26-29, 1986. Courtesy Associates, Washington D.C. 28-31.

Dole, S. L. 1978. "Technique for Preparing Highly Sinterable Oxide Powders." Materials Science and Engineering. 32:277-281.

Feduska, W, and A. O. Isenberg. 1983. "High Temperature Solid Oxide Fuel Cel1 - Technical Status." J. Power Sources. 10:89-102.

Fee, D. C., P. E. Blackburn, D. E. Busch, T. D. Claar, D. W. Dees, J. Dusek, T. E. Easler, W. A. Ellingson, B. K. Flandermeyer, R. J. Fousek, J. J. Heiberger, T. E. Kraft, S. Majumdar, C. C. McPheeters, F. C. Mrazek, J. J. Piccioola, R. B. Poeppel, and S. A. Zwick. 1986. "Monolithic Fuel Cell Development." 1986 Fuel Cell Seminar, Tucson, Arizona, October 26-29, 1986. Courtesy Associates, Washington DC. pp. 40-43. 
Fee, D. C., R. K. Steunenberg, T. D. Claar, R. B. Poeppel, and J. P. Ackerman. 1983. "Monolithic Fuel Cells," 1983 National Fuel Cell Seminar. Orlando, Florida, November 13-16, 1983, National Fuel Cell Coordinating Group.

Glushkova, V. B., and V. A. Krzhizkanovskaya. 1973. "The Interaction of $\mathrm{In}_{2} \mathrm{O}_{3}$ with $\mathrm{ZrO}_{2}$ and $\mathrm{HfO}_{2}$ at High Temperatures." Colloques Internationaux C.R.R.S. No. 205 - Etude des Transformations Cristallines a Haute Temperature.

Isenberg, A. 0. 1985. "Performance and Life Test of a Solid Oxide Fuel Cell Stack." 1985 Fuel Ce11 Seminar Abstracts. Courtesy Associates, Washington D.C. pp. 102-107.

Kravchinskaya, M. V., A. K. Kuznetsov, P. A. Takhonov and E. K. Koehler. 1973. "Phase Diagrams of the Systems $\mathrm{HfO}_{2}-\mathrm{Pr}_{2} \mathrm{O}_{3}$ and $\mathrm{Dy}_{2} \mathrm{O}_{3}-\mathrm{Pr}_{2} \mathrm{O}_{3}$." Ceramurgia International 1:14-17.

Marchant, D. D., and J. L. Bates. 1980a. "Hafnia-Rare-Earth Oxides for High Temperature MHD Electrodes." Seventh International Conference on MHD Electrical Power Generation. Massachusetts Institute of Technology, Cambridge, Massachusetts, June 16-21, 1980, Vol. 1, pp. 287-291.

Marchant, D. D., and J. L. Bates. 1980b. "Rare-Earth Hafnium Oxide Materials for Magnetohydrodynamic (MHD) General Application." The Rare Earths in Modern Science and Technology, Vol. 2. eds. G. J. McCarthy, J. J. Rhyme and H. B. Silber. Plenum Press, New York, pp. 553-558.

Penner, S. S. 1985. "Assessment of Research Needs for Advanced Fuel Cells." Energy $11:(1 / 2) ; 1985$. DOE/ER/30060-T1.

Plotkin, S. S., V. E. Plyushcev, and I. A. Rozdin. 1976. "Electrical Properties of Ceramic Containing $\mathrm{ZrO}_{2}, \mathrm{HfO}_{2}$, and $\mathrm{In}_{2} \mathrm{O}_{3} . "$ Translated from Izvestiya Academi i Nauk SSSR, Neorgahicheskie Materfaiy, 11(9):1709-1710, Plenum Publishing Corporation, New York.

Saito, Y., T. Maruyama, and Z. Kato. 1983. "Formation and Electrical Conductivity of Fluorite Solid Solution of the $\mathrm{HfO}_{2}-\mathrm{In}_{2} \mathrm{O}_{3}$ System. Zeit Physik Chemie Neue Folge, 135(201):201-215.

Swanson, et al. 1953. J. Com. Fellowship Reports, NBS 2779. 


\section{DISTRIBUTION}

No. of

Copies

OFFSITE

C. W. Griffin

Ceramatec

163 W. 1700 South

Salt Lake City, UT 84115

10 R. A. Bradley/R. Judkins

AR\&TD Fossil Energy Materials Progrann

Oak Ridge National Laboratory P.0. Box X

Oak Ridge, TN 34831

56 DOE/Office of Scientific and Technical Information

J. Carr

U.S. Department of Energy Office of Technical Coordination, Fossil Energy Route 270

Germantown, MD 20545

K. M. Myles

Argonne National Laboratory 9700 South Cass Avenue

Argonne, IL 60439
No. of

Copies

S. C. Singhal

Westinghouse Electric Corp.

Research and Development Center 2025 Beulah Road

Pittsburgh, PA 15235

K. Trimble

Gas Research Institute

8600 Byrn Mawr

Chicago, IL 60631

\section{ONSITE}

1 DOE Richland Operations Office

E. C. Norman

41 Pacific Northwest Laboratory

J. L. Bates (30)

W. J. Weber (2)

G. L. McVay

T. L. Gilbride

Technical Publishing (5)

Publishing Coordination (2) 
-

$+$

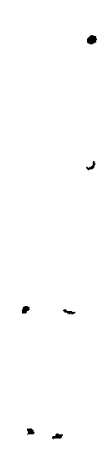

